\title{
Response of Alfalfa under Salt Stress to the Application of Potassium Sulfate Nanoparticles
}

\author{
Mahmoud Samir El-Sharkawy1, Talaat Rizk El-Beshsbeshy1, Esawy Kasem Mahmoud1, \\ Nasser Ibrahim Abdelkader ${ }^{1}$, Rania Mohamed Al-Shal ${ }^{1}$, Ali M. Missaoui ${ }^{2}$ \\ ${ }^{1}$ Soil Science and Water Department, Faculty of Agriculture, Tanta University, Tanta, Egypt \\ ${ }^{2}$ Department of Crop and Soil Sciences and Institute of Plant Breeding Genetics and Genomics, University of Georgia, Athens, \\ GA, USA \\ Email: cssamm@uga.edu
}

How to cite this paper: El-Sharkawy, M.S., El-Beshsbeshy, T.R., Mahmoud, E.K., Abdelkader, N.I., Al-Shal, R.M. and Missaoui, A.M. (2017) Response of Alfalfa under Salt Stress to the Application of Potassium Sulfate Nanoparticles. American Journal of Plant Sciences, 8, 1751-1773. https://doi.org/10.4236/ajps.2017.88120

Received: May 15, 2017

Accepted: June 30, 2017

Published: July 3, 2017

Copyright ( 2017 by authors and Scientific Research Publishing Inc. This work is licensed under the Creative Commons Attribution International License (CC BY 4.0).

http://creativecommons.org/licenses/by/4.0/ (c) (i) Open Access

\begin{abstract}
A greenhouse study was conducted to explore the effect of various rates of potassium sulfate $\left(\mathrm{K}_{2} \mathrm{SO}_{4}\right)$ nanoparticles on alfalfa (Medicago sativa L.) growth and physiological response under salt stress. One salt-tolerant genotype (Mesa-Sirsa) and one salt-sensitive genotype (Bulldog 505) were selected based on germination under salt and were planted in pots containing $2 \mathrm{~kg}$ of sand. The two genotypes were subjected to 0 and $6 \mathrm{dS} \cdot \mathrm{m}^{-1}$ salt levels using $\mathrm{CaCl}_{2} \cdot 2 \mathrm{H}_{2} \mathrm{O}$ : $\mathrm{NaCl}(2: 1)$ mixed with Hoagland solution. Three $\mathrm{K}_{2} \mathrm{SO}_{4}$ nanoparticle treatments consisting of, $1 / 4,1 / 8$, and $1 / 10$ of the potassium $(\mathrm{K})$ level in full strength Hoagland solution $\left(235 \mathrm{mg} \cdot \mathrm{L}^{-1}\right)$ were applied. Adding $\mathrm{K}_{2} \mathrm{SO}_{4}$ nanoparticles at the $1 / 8$ level resulted in the highest shoot dry weight, relative yield, root length and root dry weight in both genotypes. The different rates of $\mathrm{K}_{2} \mathrm{SO}_{4}$ nanoparticles affected significantly $\mathrm{Na} / \mathrm{K}$ ratio and the concentrations of Calcium (Ca), Phosphorus (P), Copper $(\mathrm{Cu})$, Manganese $(\mathrm{Mn})$, and Zinc ( $\mathrm{Zn})$ in plant tissue. The application of $\mathrm{K}_{2} \mathrm{SO}_{4}$ nanoparticles at the $1 / 8$ rate enhanced the plant's physiological response to salt stress by reducing electrolyte leakage, increasing catalase and proline content, and increasing antioxidant enzymes, activity. These results suggest that the application of $\mathrm{K}$ nanoparticles may have better efficiency than conventional $\mathrm{K}$ fertilizers in providing adequate plant nutrition and overcoming the negative effects of salt stress in alfalfa.
\end{abstract}

\section{Keywords}

Alfalfa, Nanoparticles, Salt Stress, Potassium

\section{Introduction}

Salt stress is one of the most important abiotic factors limiting plant growth and 
productivity, especially in arid and semi-arid regions [1]. Soil salinity reduces agricultural production worldwide. It is estimated that nearly half of the world's irrigated land is affected by salinity [2].

The presence of salt in soil solution affects plants by reducing their ability to take up water, leading to slower growth as well as the toxic effects of salt ions accumulating inside the plant [3]. In some crops species, these phases may occur simultaneously.

Alfalfa (Medicago sativa L.) is the most commonly grown forage worldwide [4], because of its lower production costs, high quality (digestibility and protein content) and seasonal distribution through the year [5]. Global alfalfa production is estimated around 454 million tons per year [6]. Alfalfa is considered moderately tolerant to salt and can withstand an equivalent of $20 \mathrm{mM}$ sodium chloride [1]. However, research has shown that a $7 \%$ decrease in alfalfa yields can be expected with each $1 \mathrm{dS} \cdot \mathrm{m}^{-1}$ increase in saturation extract salinity [7]. Emam et al. [8] studied the effect of salt stress on two genotypes of alfalfa and found that dry matter production decreased under high salinity level treatments as a result of salt accumulation followed by toxic effect of salt. They also found that $\mathrm{Na}$ accumulation increased with increasing salinity level in both cultivars and that $\mathrm{Na}$ sequestration in one genotype was lower due to an exclusion mechanism of $\mathrm{Na}$ ions.

Potassium $(\mathrm{K})$ is an essential nutrient and is also the most abundant cation in plants [9]. Potassium plays a critical role in plant growth and metabolism, and it contributes significantly to the survival of plants under various biotic and abiotic stresses. Potassium fertilizer is very important for crop production and quality. As a consequence, potash consumption has increased dramatically in most regions of the world [10]. A strong positive relationship between $\mathrm{K}$ fertilizer input and grain yield was shown by Dong et al. [11]. Potassium deficiency can occur under salt stress because the high concentrations of $\mathrm{Na}$ inhibit $\mathrm{K}$ activity in the soil solution, result in a decrease of $\mathrm{K}$ availability. Sodium also interferes with $\mathrm{K}$ translocation from root to shoot, especially at low K status [12]. Under salt stress, the plasma membrane disintegrates and favors $\mathrm{K}$ leaking, resulting in a rapid decline in cytosolic K [13]. Mian et al. [14] reported that an increase in K supply corresponded with higher $\mathrm{K}$ accumulation in plant tissue, which reduced $\mathrm{Na}$ concentration and resulted in a higher K/Na ratio. Munns and Tester [15] suggested that plants have a $\mathrm{Na}$ exclusion mechanism that maintains a low level of $\mathrm{Na}$ in the leaves during salt stress. Potassium is also a major osmolyte in plant tissue and plays an important role in maintaining cell turgor and osmotic adjustment.

Development of new types of fertilizers using innovative nanotechnology presents opportunities to potentially improve the effectiveness of fertilizers and to significantly enhance crop production needed to meet the future demands of the growing global population [16]. Scientists are striving to develop new techniques that could boost the functions of new fertilizers. Recent studies indicate that some engineered nanomaterials (NM) are able to enhance plant-growth in certain concentration ranges and could be used as nanofertilizers in agriculture 
to improve crop yields and minimize environmental pollution [17]. Nanomaterials (NM) are defined as particles with a single unit between 1 and 100 nanometers $(\mathrm{nm})$ in size in at least one dimension. Accordingly, nanofertilizers are either NM which can supply one or more nutrients to the plants and enhance their growth and yields, or improve the performance of the conventional fertilizer without directly providing crops with nutrients [17] [18]. Furthermore, nanofertilizers could be classified as macronutrient and micronutrient nanofertilizers. Compared with conventional types, nanofertilizers are expected to significantly improve crop growth and increase yield by enhancing the efficiency of fertilizer use, reduce nutrient losses, and/or minimize their adverse environmental impacts [19] [20].

The aim of this work is to explore the effect of various rates of potassium sulfate nanoparticles on alfalfa biomass yield and physiological response under salt stress conditions.

\section{Materials and Methods}

Two alfalfa genotypes were selected based on their germination response under increasing salt concentrations. The genotype Mesa-Sirsa was salt tolerant and Bulldog 505 was susceptible. Seeds from the two genotypes were planted in pots containing $2 \mathrm{Kg}$ of sand and kept at field capacity (Table 1). The experiment layout was a split-plot design with three replications. The main plots were salt concentrations of 0 and $6 \mathrm{dS} \cdot \mathrm{m}^{-1}$ and the subplots were rates of potassium sulfate nanoparticles. Alfalfa plants were gradually subjected to two levels of salt concentrations starting at four weeks after planting. Calcium chloride $\left(\mathrm{CaCl}_{2} \cdot 2 \mathrm{H}_{2} \mathrm{O}\right)$ and sodium chloride $(\mathrm{NaCl})$ were mixed in a 2:1 proportion $\left(\mathrm{CaCl}_{2}: \mathrm{NaCl}\right)$ and added to Hoagland solution to make two nutrient solutions of 0 and $6 \mathrm{dS} \cdot \mathrm{m}^{-1}$ electrical conductivity.

The treatments consisted of a control with Hoagland solution without salt, a control with Hoagland solution (235 ppm K) at $6 \mathrm{dS} \cdot \mathrm{m}^{-1} \mathrm{EC}$, Hoagland solution

Table 1. Physical characteristics and chemical composition of the soil used to study the response of two alfalfa genotypes evaluated under two salt levels $\left(0\right.$ and $6 \mathrm{dS} \cdot \mathrm{m}^{-1}$ Electrical Conductivity) and three treatments of potassium nanoparticles $(1 / 10,1 / 8$, and $1 / 4)$ of the full $\mathrm{K}$ rate in Hoagland solution.

\begin{tabular}{ccccccccccccc}
\hline Sand & $100.0 \%$ & \multicolumn{10}{c}{ Mineral concentration $\left(\mathrm{mg}^{-\mathrm{kg}^{-1}}\right)$} \\
\hline Silt & $0.0 \%$ & $\mathrm{Ca}$ & $\mathrm{Mg}$ & $\mathrm{Na}$ & $\mathrm{K}$ & $\mathrm{Cl}$ & $\mathrm{NH}_{4}-\mathrm{N}$ & $\mathrm{NO}_{3}-\mathrm{N}$ & $\mathrm{P}$ & $\mathrm{Fe}$ \\
Clay & $0.0 \%$ & 35.17 & 5.94 & $<1.79$ & 2.55 & 8.70 & $<6.40$ & $<0.17$ & 0.97 & 5.46 \\
Soil Type & Sand & & & & & & & & & \\
EC & $0.011 \mathrm{dS} \cdot \mathrm{m}^{-1}$ & $\mathrm{Zn}$ & $\mathrm{B}$ & $\mathrm{Mn}$ & $\mathrm{Cu}$ & $\mathrm{Mo}$ & $\mathrm{Cd}$ & $\mathrm{Cr}$ & $\mathrm{Ni}$ & $\mathrm{Pb}$ \\
pH & 6.68 & & & & & & & & & \\
CEC & 0.21 meq. $100 \mathrm{~g}^{-1}$ & 0.33 & 0.775 & 0.88 & 0.29 & $<0.04$ & $<0.04$ & 0.04 & $<0.04$ & 0.36 \\
OM & $0.01 \%$ & & & & & & & & & \\
\hline
\end{tabular}

EC: Electrical conductivity in dS $\mathrm{m}^{-1}$. CEC: Cation exchange capacity in meq. $100 \mathrm{~g}^{-1}$ soil. OM: Organic matter. 
with potassium sulfate nanoparticles at $1 / 10 \mathrm{~K}$ level of the control under salt, Hoagland solution with potassium sulfate nanoparticles at $1 / 8$ of the control, and a Hoagland solution with potassium sulfate nanoparticles at $1 / 4$ of the control. The potassium sulfate nanoparticles were added in two applications, the first application was five weeks after planting and the second was after the first cut (nine weeks after planting). The plants were harvested twice, once 70 days after planting, and the second cut was harvested 60 after the first cut. Plant biomass in green house was determined by measuring the shoot and root dry weights using a digital scale with $0.001 \mathrm{~g}$ sensitivity. Root length was measured in centimeters. The number of tillers was counted at harvest time.

Relative water content of shoots was measured according to Turner [21] using the equation:

$$
\mathrm{RWC}=(\mathrm{FW}-\mathrm{DW}) /(\mathrm{TW}-\mathrm{DW})
$$

where, $\mathrm{FW}=$ fresh weight, $\mathrm{TW}=$ turgor weight, $\mathrm{DW}=$ dry weight. Dry weight was estimated by drying the samples at $80^{\circ} \mathrm{C}$ for $48 \mathrm{~h}$ in a convection oven. Turgor weight was determined by floating the shoots on water at room temperature for $48 \mathrm{~h}$. Relative yield was determined according to Isla and Aragüés [22] by dividing the actual yield in each saline treatment by the highest yield observed.

\subsection{Salt Stress Response}

Free proline content in plant tissue was determined according to the method of Bates et al. [23] where, $100 \mathrm{mg}$ of plant material was homogenized in $2 \mathrm{ml}$ of $3 \%$ aqueous sulfosalicylic acid. The homogenate was centrifuged at $13,000 \times \mathrm{g}$ for 10 minutes at $4^{\circ} \mathrm{C}$, then $1 \mathrm{ml}$ of supernatant was placed in a reaction test tube and reacted with $1 \mathrm{ml}$ of acid-ninhydrin and $1 \mathrm{ml}$ glacial acetic acid. The test tubes were heated in a bath of boiling water for 1 hour and the reaction was terminated in an ice bath. The reaction mixture was extracted with $2 \mathrm{ml}$ of toluene, and mixed vigorously by vortex. The toluene layer separated at room temperature and the absorbance of chromophore containing toluene was measured at $520 \mathrm{~nm}$ using a spectrophotometer (Varian Cary $50 \mathrm{UV}-\mathrm{Vis}$ spectrophotometer, USA), using pure toluene as the blank. Standard curves were prepared with each assay using standard proline in $3 \%$ sulfosalicylic acid solution. Proline content was expressed as micromoles per gram $\left(\mu \mathrm{M} \mathrm{g}^{-1}\right)$ of fresh weight of plant material.

Electrolyte leakage (EL) was determined as described by Lutts et al. [24], where $200 \mathrm{mg}$ of fresh leaves from the alfalfa plants were cut and placed in test tubes containing $10 \mathrm{ml}$ of distilled deionized water. The tubes were incubated at $25^{\circ} \mathrm{C}$ on a rotary shaker for 24 hours and, subsequently, the electrical conductivity of the solution (Lt) was determined. Samples were then autoclaved at $120^{\circ} \mathrm{C}$ for 20 minutes and the final electrical conductivity (L0) was obtained after equilibration at $25^{\circ} \mathrm{C}$. Measurements of electrical conductivity were made using a conducti-meter H1993310 (HANA Instruments Romania). The electrolyte leakage was expressed as 


$$
\mathrm{EL}(\%)=(\mathrm{Lt} / \mathrm{L} 0) \times 100
$$

\subsection{Antioxidant Enzymes Analysis}

For this analysis, $200 \mathrm{mg}$ of leaf samples were homogenized with $50 \mathrm{mM}$ sodium phosphate buffer (PH 7.0) containing $1 \mathrm{mM}$ ethylenediaminetetraacetic acid (EDTA) and $2 \%(\mathrm{w} / \mathrm{v})$ polyvinylpyrrolidone (PVP). The entire extraction procedure was carried out at $4^{\circ} \mathrm{C}$. The homogenate was centrifuged at $10,000 \times \mathrm{g}$ for $15 \mathrm{~min}$ at $4^{\circ} \mathrm{C}$, and the supernatant was collected and used for the assays of enzyme activity.

Catalase (CAT, EC 1.11.1.6) activity was measured as the rate of $\mathrm{H}_{2} \mathrm{O}_{2}$ disappearance at $240 \mathrm{~nm}$ according to Bergmeyer and Gawehn [25] by adding $100 \mu \mathrm{l}$ leaf crude extract to the solution of mixture containing $50 \mathrm{mM}$ sodium phosphate buffer ( $\mathrm{pH} 7.0)$ and $2 \% \mathrm{H}_{2} \mathrm{O}_{2}$. The activity was calculated as units ( $\mu \mathrm{mol}$ $\mathrm{H}_{2} \mathrm{O}_{2}$ consumed per minute) per gram fresh weight.

Superoxide dismutase (SOD, EC 1.15.1.1) activity was assayed spectrophotometrically as the inhibition of photochemical reduction of nitro-blue tetrazolium (NBT) at $560 \mathrm{~nm}$ according to the method of Beauchamp and Fridovich [26].

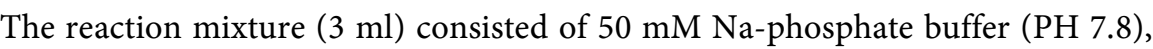
$13 \mathrm{mM}$ L-methionine, $75 \mu \mathrm{M}$ NBT, $10 \mu \mathrm{M}$ EDTA, $2.0 \mu \mathrm{M}$ riboflavin and $0.3 \mathrm{ml}$ enzyme extract. The test tubes containing reaction mixtures were weighed for 10 min under $4000 \mathrm{~lx}$ at $35^{\circ} \mathrm{C}$. One-unit SOD activity was defined as the amount of enzyme required to cause a $50 \%$ inhibition of the rate of NBT reduction measured at $560 \mathrm{~nm}$.

\subsection{Statistical Analysis}

Analysis of variance (ANOVA) was conducted on the data from two experiments using PROC GLM $(\alpha=0.05)$ in SAS 9.4 (SAS Institute Inc., Cary, NC). Replications were considered random and all other variables were considered fixed effects. Means of all variables were separated using Fisher's protected LSD test.

\section{Results}

\subsection{Soil Properties}

An overall change in mineral composition in the soil following the second harvest was observed compared to the control (Table $2 \&$ Table 3 ). There were significant changes $(p<0.01)$ in $\mathrm{pH}$, cation exchange capacity (CEC), $\mathrm{Ca}, \mathrm{Na}, \mathrm{K}$, and $\mathrm{Mg}$ as a result of the salt concentration (Table 2). There was no significant interaction between genotypes and $\mathrm{K}$ nanoparticle rates. The only interaction observed $(p<0.01)$ was between genotypes and salt level for soil $\mathrm{pH}$. The rates of potassium sulfate nanoparticles had a significant effect $(p<0.01)$ on $\mathrm{pH}, \mathrm{EC}$, $\mathrm{CEC}, \mathrm{Ca}, \mathrm{K}, \mathrm{Mg}, \mathrm{Na}, \mathrm{Fe}$, and $\mathrm{Mn}$. Under salt stress, adding $\mathrm{K}$ nanoparticles reduced the $\mathrm{pH}$ compared to the no-salt control and the control under salt (full rate conventional $\mathrm{K}$ ). The increase in salt concentration led to an increase in 
Table 2. Mean squares and significance of soil properties of alfalfa genotypes evaluated under two salt levels $\left(0\right.$ and $6 \mathrm{dS} \cdot \mathrm{m}^{-1}$ Electrical Conductivity) and three treatments of potassium nanoparticle rates $(1 / 10,1 / 8$, and $1 / 4)$ of the full $\mathrm{K}$ rate in Hoagland solution.

\begin{tabular}{|c|c|c|c|c|c|c|c|c|c|c|c|c|}
\hline Source of variation & DF & $\mathrm{pH}$ & $\mathrm{EC}\left(\mathrm{dS} \cdot \mathrm{m}^{-1}\right)$ & CEC & $\mathrm{Ca}$ & $\mathrm{K}$ & $\mathrm{Mg}$ & $\mathrm{Na}$ & $\mathrm{P}$ & $\mathrm{Zn}$ & $\mathrm{Fe}$ & $\mathrm{Mn}$ \\
\hline Genotypes & 1 & 0.0003 & $0.0919^{*}$ & 0.15 & 4900.67 & 273.75 & 62.16 & 8.66 & 76.50 & 0.001 & 0.30 & 0.06 \\
\hline Nano- $\mathrm{K}_{2} \mathrm{SO}_{4}$ rates & 3 & $0.585^{\star *}$ & $0.1667^{\star \star}$ & $9.44^{\star \star}$ & $129882.5^{\star \star}$ & $55076.90^{\star *}$ & $1726.65^{\star *}$ & $5953.01^{\star *}$ & 7.30 & 0.008 & $2.60^{\star *}$ & $0.66^{*}$ \\
\hline $\begin{array}{l}\text { Genotypes } \times \text { salt } \\
\text { concentration }\end{array}$ & 1 & $0.168^{\star *}$ & 0.0002 & 0.002 & 96.333 & 663.05 & 8.50 & 430.80 & 0.66 & 0.002 & 0.03 & 0.03 \\
\hline $\begin{array}{c}\text { Genotypes } \times \text { Nano- } \mathrm{K}_{2} \mathrm{SO}_{4} \\
\text { rates }\end{array}$ & 3 & 0.016 & 0.0118 & 0.242 & 5846.28 & 353.95 & 76.85 & 420.38 & 18.36 & 0.009 & 0.48 & 0.24 \\
\hline Error & 18 & 0.001 & & 0.28 & 5328.47 & 452.33 & 72.63 & 225.39 & 44.98 & 0.011 & 0.22 & 0.11 \\
\hline LSD & & 0.072 & 0.10 & 0.40 & 55.20 & 15.74 & 6.47 & 10.99 & 5.02 & 0.081 & 0.37 & 0.25 \\
\hline
\end{tabular}

DF: Degree of freedom, LSD: Least Significant Difference at $\alpha=0.05 .{ }^{\star}$ Significant at $P<0.05 .{ }^{*}$ Significant at $P<0.01$.

$\mathrm{CEC}, \mathrm{Ca}, \mathrm{Mg}$, and $\mathrm{Na}$, compared to the no salt control (Table 3). Under salt stress, $\mathrm{CEC}, \mathrm{Ca}, \mathrm{Mg}, \mathrm{Na}, \mathrm{Fe}$ and $\mathrm{Mn}$ concentrations decreased in the soil after harvest in both alfalfa genotypes at all levels of $\mathrm{K}$ nanoparticle treatments. In the salt sensitive Bulldog, the highest values were observed with $1 / 8$ rate of $\mathrm{K}_{2} \mathrm{SO}_{4}$ nanoparticles which recorded $4.61 \mathrm{Meq} .100 \mathrm{~g}^{-1}$ for CEC, $654 \mathrm{mg} \cdot \mathrm{kg}^{-1}$ for $\mathrm{Ca}$, 66.57 for $\mathrm{Mg}, 156.5$ for $\mathrm{Na}, 4.30$ for $\mathrm{Fe}$ and $1.68 \mathrm{mg} \cdot \mathrm{kg}^{-1}$ for $\mathrm{Mn}$, respectively (Table 3). In the salt-tolerant Mesa-Sirsa, the highest values were observed with $1 / 10$ rate of $\mathrm{K}_{2} \mathrm{SO}_{4}$ nanoparticles which recorded $4.44 \mathrm{Meq} .100 \mathrm{~g}^{-1}$ for CEC, 627.33 for $\mathrm{Ca}, 62.37$ for $\mathrm{Mg}, 154.67$ for $\mathrm{Na}, 4.87$ for Fe, and $1.77 \mathrm{mg} \cdot \mathrm{kg}^{-1}$ for $\mathrm{Mn}$, respectively. On the other hand, residual potassium and phosphorous levels in the soil were lower after harvesting in the treatments receiving $\mathrm{K}_{2} \mathrm{SO}_{4}$ nanoparticles compared to the control (full rate conventional $\mathrm{K}$ ) under salt, while zinc levels increased following the addition of nanoparticle- $\mathrm{K}_{2} \mathrm{SO}_{4}$ compared to the control under salt stress (Table 3).

\subsection{Plant Biomass}

There were significant differences between the two genotypes $(p<0.01)$ for shoot dry weight and root length. Salt levels had a significant effect $(p<0.05)$ on shoot dry weight, root length, and root dry weight (Table 4). Increasing salt concentration caused a decrease in plant shoot dry weight, root length, root dry weight, and relative yield in both genotypes compared to the no-salt control (0 $\mathrm{dS} \cdot \mathrm{m}^{-1}$ ). The magnitude of the decrease was larger for Bulldog 505 (Table 5). There was a significant difference in response to the application of $\mathrm{K}$ nanoparticles $(p<0.01)$ in shoot dry weight, and relative yield (Table 4$)$. Adding $\mathrm{K}$ nanoparticles at the $1 / 8$ level produced the highest shoot dry weights in both genotypes, with $3.33 \mathrm{~g}$ for Bulldog and $2.66 \mathrm{~g}$ for Mesa-Sirsa compared to the conventional potassium full rate under $6 \mathrm{dS} \cdot \mathrm{m}^{-1}$ salt level (Table 5). The $1 / 8$ rate also resulted in the highest relative yield in both genotypes, with 74.05\% for Bull$\operatorname{dog} 505 \%$ and $69.94 \%$ for Mesa-Sirsa, compared to the conventional K full rate 


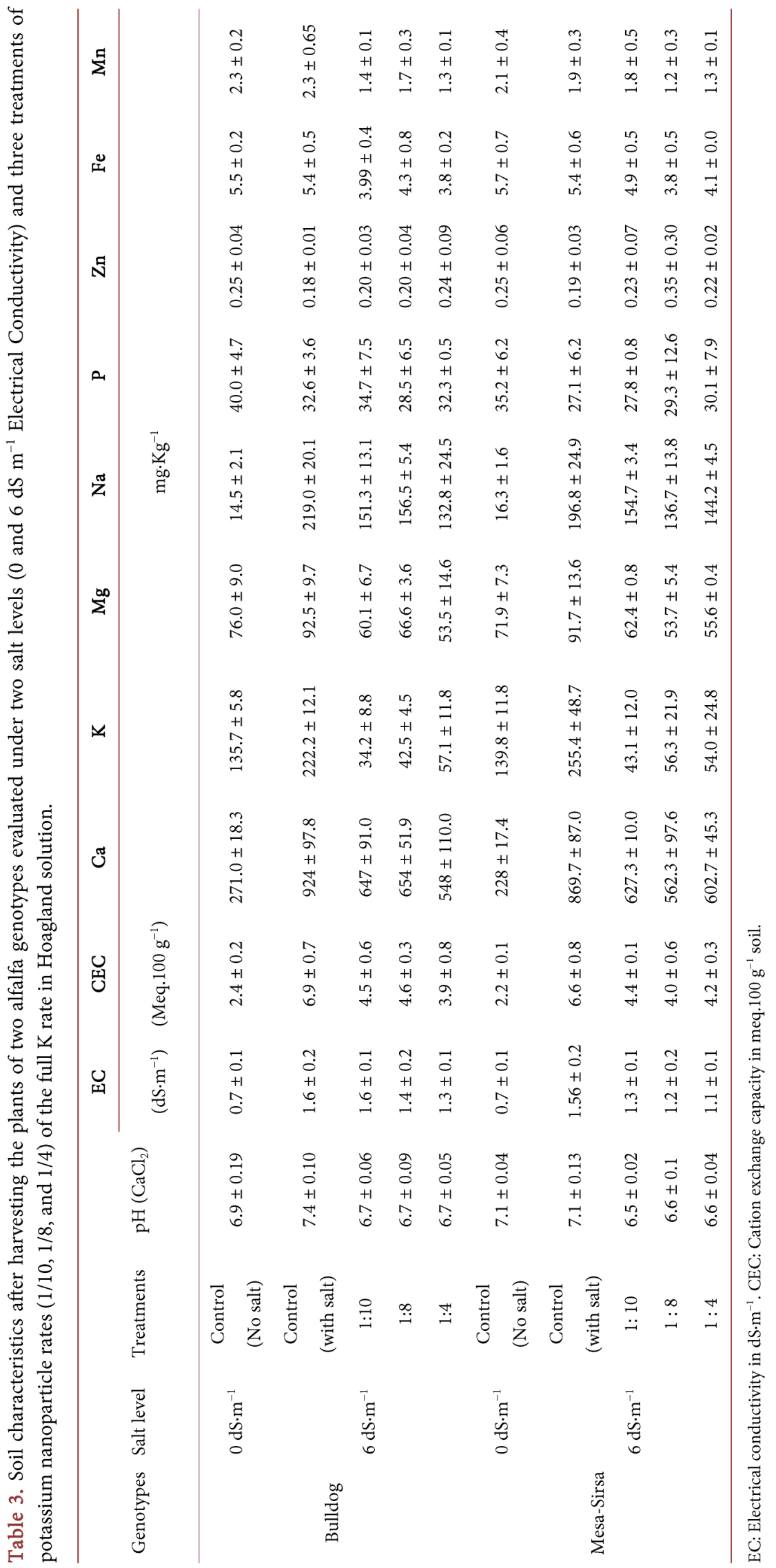


Table 4. Mean squares for shoot dry weight $(\mathrm{g})$, number of tillers, root dry weight $(\mathrm{g})$, root length $(\mathrm{cm})$, and relative yield $(\%)$ of two alfalfa genotypes evaluated under two salt levels ( 0 and $6 \mathrm{dS} \cdot \mathrm{m}^{-1}$ Electrical Conductivity) and three treatments of potassium nanoparticle rates $(1 / 10,1 / 8$, and $1 / 4)$ of the full $\mathrm{K}$ rate in Hoagland solution.

\begin{tabular}{|c|c|c|c|c|c|c|}
\hline Source of variation & $\mathrm{DF}$ & Shoot dry weight & Plant height & Root length & Root dry weight & Relative yield \\
\hline Genotypes & 1 & $2.54^{\star *}$ & 24.23 & $120.38^{\star *}$ & 1.45 & 27.47 \\
\hline Salt conc. & 1 & $3.00^{* *}$ & 190.37 & $163.36^{* *}$ & $12.27^{\star *}$ & $14.54^{* *}$ \\
\hline Cuts & 1 & $66.19^{\star *}$ & 79.09 & ---- & ----- & $6725.41^{* *}$ \\
\hline Genotypes $\times$ salt conc & 1 & 0.19 & 1.95 & 3.83 & 0.35 & 4.60 \\
\hline Nano- $\mathrm{K}_{2} \mathrm{SO}_{4}$ rates & 3 & $0.81^{\star *}$ & 30.03 & $78.24^{\star *}$ & $16.74^{\star *}$ & $424.04^{*}$ \\
\hline Genotypes $\times$ Nano- $\mathrm{K}_{2} \mathrm{SO}_{4}$ rates & 3 & 0.15 & 4.84 & 4.55 & 0.096 & 32.35 \\
\hline Genotypes $\times$ Nano- $\mathrm{K}_{2} \mathrm{SO}_{4}$ rates $\times$ Cuts & 1 & 0.33 & 5.55 & ---- & --- & 63.31 \\
\hline Nano- $\mathrm{K}_{2} \mathrm{SO}_{4}$ rates $\times$ Cuts & 3 & $3.30^{\star *}$ & 40.09 & ---- & --- & $2056.12^{\star *}$ \\
\hline LSD & & 0.1877 & 2.318 & 2.7458 & 0.5374 & 5.4036 \\
\hline
\end{tabular}

DF: Degree of freedom, LSD: Least Significant Difference at $\alpha=0.05 .{ }^{*}$ Significant at $P<0.05{ }^{*}$ Significant at $P<0.01$.

Table 5. Shoot dry weight $(\mathrm{g})$, plant height $(\mathrm{cm})$, root length $(\mathrm{cm})$, and relative yield $(\%)$ of two alfalfa genotypes evaluated under two salt levels $\left(0\right.$ and $6 \mathrm{dS} \cdot \mathrm{m}^{-1}$ Electrical Conductivity) and three treatments of potassium nanoparticle rates $(1 / 10,1 / 8$, and 1/4) of the full $\mathrm{K}$ rate in Hoagland solution.

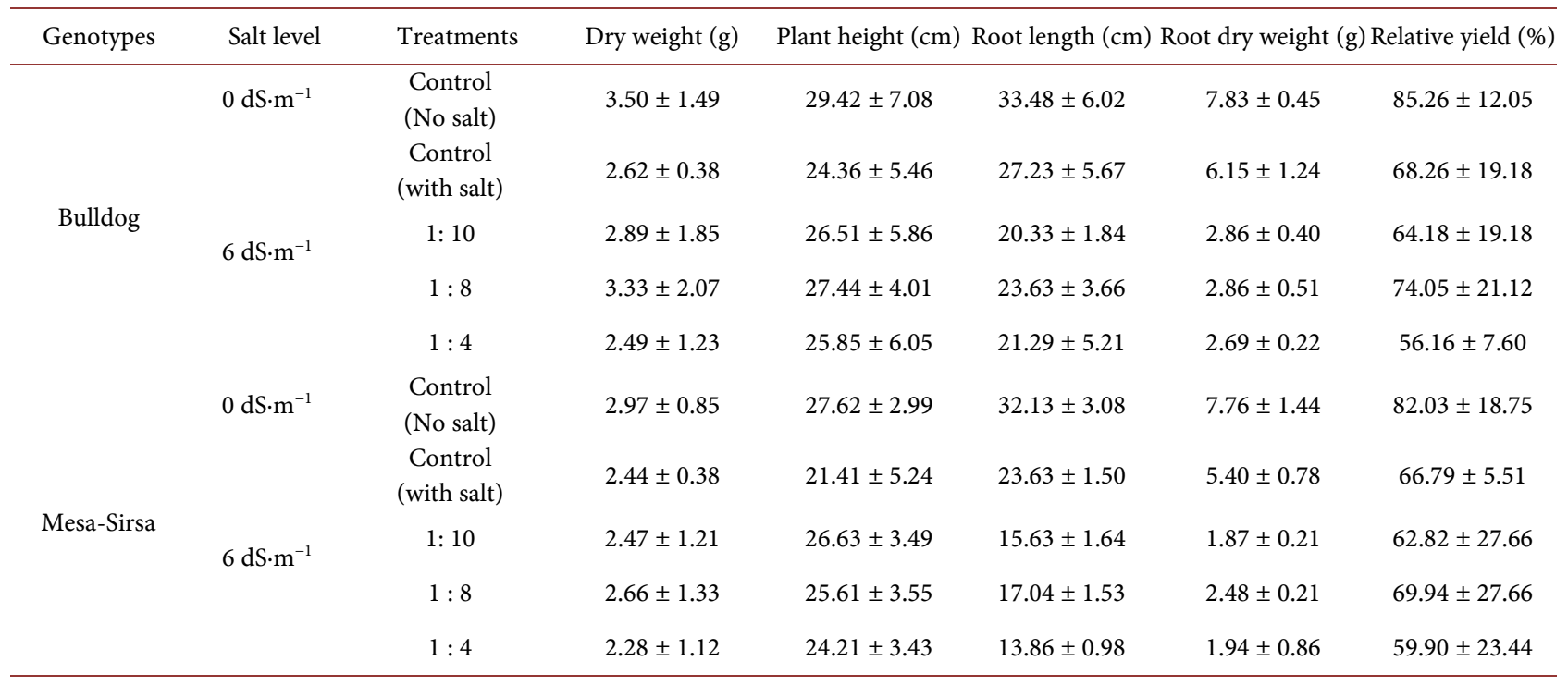

under salt. It seems like potassium sulfate nanoparticles stored in the soil during the first cut were released in the second cut leading to a higher relative yield in the second cut than the first cut (data not shown). There was no effect on plant height in both genotypes. The application of $\mathrm{K}$ nanoparticles resulted in significant differences $(p<0.01)$ in root length and root dry weight (Table 4 ). Root length and root dry weight were overall lower in the $\mathrm{K}$ nanoparticle rates compared to the conventional $\mathrm{K}$ full rate under salt stress. However, the application of $1 / 8$ level of $\mathrm{K}$ nanoparticles resulted in the highest values in root length (23.6 $\mathrm{cm}$ for Bulldog 505 and $17.04 \mathrm{~cm}$ for Mesa-Sirsa) and in root weights (2.86 $\mathrm{g}$ for 
Bulldog 505 and $2.48 \mathrm{~g}$ for Mesa-Sirsa) compared to 1/4 and 1/10 rates (Table $5)$. There was no interaction between genotypes and salt concentrations or genotypes by $\mathrm{K}$ nanoparticle rates on any of the biomass traits, but there was a significant interaction between nanoparticle rates and cuts for shoot dry weight and relative yield $(p<0.05)$. The interaction was mostly due to the magnitude of shoot dry weights between the two cuts.

\subsection{Plant tissue Chemical Characteristics}

\subsubsection{Macro-Elements Concentrations}

There was a significant difference between the genotypes in both $\mathrm{Na} / \mathrm{K}(p<0.05)$ ratio and $\mathrm{Ca}$ accumulation in plant tissue $(p<0.01)$. Under salt stress, plants of the genotype Mesa-Sirsa had higher $\mathrm{Na} / \mathrm{K}$ ratios at all $\mathrm{K}$ levels compared to the genotype Bulldog 505 (Table 7). The genotype Mesa-Sirsa also accumulated more Ca compared to Bulldog 505. Increasing salt concentration to $6 \mathrm{dS} \cdot \mathrm{m}^{-1}$ significantly affected $(p<0.01) \mathrm{Na} / \mathrm{K}$ ratio, $\mathrm{Ca}, \mathrm{Mg}$, and $\mathrm{S}$ concentrations in plant tissue. Calcium concentration increased in both genotypes under salt while $\mathrm{Mg}$ and S decreased compared to the no-salt control (Table 7). The increase in Ca contents in plant tissue under salt stress, in comparison to the control without salt is expected, as the solution used to raise the salt concentration contained calcium chloride, and this has favored its absorption and accumulation [27]. Plant magnesium content in plant tissue decreased under salt stress regardless of the treatment, and was lower in both genotypes compared to the no-salt control. The 1/4 rate of $\mathrm{K}$ nanoparticles recorded the highest magnesium values in both genotypes ( $0.38 \%$ in Bulldog and $0.27 \%$ in Mesa-Sirsa) compared to the other $\mathrm{K}$ treatments under salt stress (Table 7). Phosphorous concentration in plant tissues was higher under $\mathrm{K}$ noanoparticles in both genotypes compared to the nosalt control and the control with conventional $\mathrm{K}$ under salt. The highest accumulation of phosphorus was observed with the $1 / 8$ rate in the Bulldog genotype $(0.4 \%)$ and with the $1 / 10$ rate in Mesa-Sirsa $(0.44 \%)$. There was no significant difference in nitrogen and sulfur content between salt concentrations or $\mathrm{K}$ treatments. Application of $\mathrm{K}_{2} \mathrm{SO}_{4}$ nanoparticles had a significant effect $(p<0.01)$ on the $\mathrm{Na} / \mathrm{K}$ ratio, as well as $\mathrm{Ca}$ and $\mathrm{P}$ concentration in plant tissue (Table 6). All the nanoparticles rates resulted in higher $\mathrm{Na} / \mathrm{K}$ ratios in both genotypes compared to the no-salt control and to the control with full rate of conventional $\mathrm{K}$ under salt stress. The magnitude of the ratios was higher in the salt-tolerant genotype Mesa-Sirsa (Table 7). The $1 / 4$ rate of $\mathrm{K}$ nanoparticles resulted in the lowest $\mathrm{Na} / \mathrm{K}$ ratio in both genotypes, with 13.81 in the salt sensitive Bulldog and 26.80 in the salt tolerant Mesa-Sirsa (Table 7 ). The $1 / 8$ rate of $\mathrm{K}$ nanoparticles resulted in the highest $\mathrm{Ca}$ concentration in plant tissues of both genotypes, recording 3.38\% and 3.92\% in Bulldog and Mesa-Sirsa, respectively.

\subsubsection{Micro-Elements Concentrations}

Increasing the salt level to $6 \mathrm{dS} \cdot \mathrm{m}^{-1}$ significantly $(p<0.01)$ affected the concentration of boron and cadmium in plant tissue (Table 8 ). Boron was lower under salt stress and cadmium was higher compared to the no-salt treatment (Table 9). 
Table 6. Mean squares for chemical composition (macro-elements) in plant tissue of two alfalfa genotypes evaluated under two salt levels ( 0 and $6 \mathrm{dS} \cdot \mathrm{m}^{-1}$ Electrical Conductivity) and three treatments of potassium nanoparticle rates $(1 / 10,1 / 8$, and $1 / 4)$ of the full $\mathrm{K}$ rate in Hoagland solution.

\begin{tabular}{cccccccc}
\hline Source of variation & $\mathrm{DF}$ & $\mathrm{Na} / \mathrm{K}$ & $\mathrm{Ca}$ & $\mathrm{Mg}(\%)$ & $\mathrm{P}(\%)$ & $\mathrm{N}(\%)$ & $\mathrm{S}(\%)$ \\
\hline Genotypes & 1 & $290.93^{*}$ & $3.78^{* *}$ & 0.01 & 0.0005 & 0.006 & 0.0007 \\
Salt conc. & 1 & $1388.96^{* *}$ & 1.00 & $0.29^{* *}$ & 0.003 & 0.005 & $0.014^{* *}$ \\
$\begin{array}{c}\text { Nano- } \mathrm{K}_{2} \mathrm{SO}_{4} \text { rates } \\
\text { Genotypes } \times \text { salt } \\
\text { concentration }\end{array}$ & 3 & $458.50^{* *}$ & $2.06^{* *}$ & 0.02 & $0.02^{*}$ & 0.037 & 0.0003 \\
$\begin{array}{c}\text { Genotypes } \times \text { Nano- } \mathrm{K}_{2} \mathrm{SO}_{4} \\
\text { rates }\end{array}$ & 3 & 55.24 & 0.06 & 0.01 & 0.0003 & 0.021 & 0.0004 \\
Error & 20 & 48.52 & 0.34 & 0.01 & 0.004 & 0.024 & 0.0003 \\
LSD & & 5.31 & 0.4747 & 0.078 & 0.05 & 0.12 & 0.022 \\
\hline
\end{tabular}

DF: Degree of freedom, LSD: Least Significant Difference at $\alpha=0.05 .{ }^{\star}$ Significant at $P<0.05{ }^{*}$ Significant at $P<0.01$.

Table 7. Average mineral composition of macro-elements in plant tissue of two alfalfa genotypes evaluated under two salt levels $\left(0\right.$ and $6 \mathrm{dS} \cdot \mathrm{m}^{-1}$ Electrical Conductivity) and three treatments of potassium nanoparticle rates $(1 / 10,1 / 8$, and $1 / 4)$ of the full $\mathrm{K}$ rate in Hoagland solution.

\begin{tabular}{|c|c|c|c|c|c|c|c|c|}
\hline Genotypes & Salt level & Treatments & $\mathrm{Na} / \mathrm{K}(\%)$ & $\mathrm{Ca}(\%)$ & $\operatorname{Mg}(\%)$ & $\mathrm{P}(\%)$ & $\mathrm{N}(\%)$ & S (\%) \\
\hline \multirow{5}{*}{ Bulldog } & $0 \mathrm{dS} \cdot \mathrm{m}^{-1}$ & $\begin{array}{l}\text { Control } \\
\text { (no salts) }\end{array}$ & $1.02 \pm 0.45$ & $0.00148 \pm 0$ & $20.55 \pm 0.1$ & $0.26 \pm 0.03$ & $32.95 \pm 0.1$ & $0.31 \pm 0.0$ \\
\hline & & $\begin{array}{c}\text { Control } \\
\text { (with salts) }\end{array}$ & $4.33 \pm 0.4$ & $2.20 \pm 0.3$ & $0.18 \pm 0.0$ & $0.27 \pm 0.0$ & $3.08 \pm 0.2$ & $0.23 \pm 0.0$ \\
\hline & $6 \mathrm{dS} \cdot \mathrm{m}^{-1}$ & $1: 10$ & $15.94 \pm 11.9$ & $2.25 \pm 0.2$ & $0.19 \pm 0.0$ & $0.30 \pm 0.1$ & $3.03 \pm 0.1$ & $0.21 \pm 0.0$ \\
\hline & & $1: 8$ & $24.45 \pm 7.1$ & $3.38 \pm 0.4$ & $0.25 \pm 0.0$ & $0.40 \pm 0.1$ & $2.89 \pm 0.1$ & $0.21 \pm 0.0$ \\
\hline & & $1: 4$ & $13.81 \pm 11.4$ & $4 \quad 2.76 \pm 1.2$ & $0.38 \pm 0.2$ & $0.33 \pm 0.1$ & $3.07 \pm 0.1$ & $0.25 \pm 0.1$ \\
\hline \multirow{5}{*}{ Mesa-Sirsa } & $0 \mathrm{dS} \cdot \mathrm{m}^{-1}$ & $\begin{array}{l}\text { Control } \\
\text { (no salts) }\end{array}$ & $1.87 \pm 0.39$ & $1.90 \pm 0.8$ & $0.45 \pm 0.2$ & $0.21 \pm 0.0$ & $3.06 \pm 0.3$ & $0.28 \pm 0.1$ \\
\hline & & $\begin{array}{c}\text { Control } \\
\text { (with salts) }\end{array}$ & $7.54 \pm 5.2$ & $2.34 \pm 0.8$ & $0.19 \pm 0.1$ & $0.27 \pm 0.1$ & $3.01 \pm 0.1$ & $0.22 \pm 0.0$ \\
\hline & \multirow[t]{3}{*}{$6 \mathrm{dS} \cdot \mathrm{m}^{-1}$} & $1: 10$ & $29.99 \pm 10.3$ & $33.74 \pm 0.8$ & $0.28 \pm 0.0$ & $0.44 \pm 0.0$ & $2.97 \pm 0.2$ & $0.24 \pm 0.0$ \\
\hline & & $1: 8$ & $26.80 \pm 1.3$ & $3.92 \pm 0.2$ & $0.25 \pm 0.0$ & $0.37 \pm 0.0$ & $2.83 \pm 0.2$ & $0.21 \pm 0.0$ \\
\hline & & $1: 4$ & $24.75 \pm 2.8$ & $3.82 \pm 0.3$ & $0.27 \pm 0.0$ & $0.35 \pm 0.0$ & $2.86 \pm 0.1$ & $0.21 \pm 0.0$ \\
\hline
\end{tabular}

Nanoparticle $\mathrm{K}_{2} \mathrm{SO}_{4}$ treatments affected $\mathrm{Cu}, \mathrm{Mn}$, and $\mathrm{Zn}$ content in plant tissues $(p<0.01)$. Cupper concentration increased under salt stress regardless of the $\mathrm{K}$ treatment compared to the no-salt control. Application of $\mathrm{K}$ nanoparticles reduced the amount of cupper compared to the control with conventional full $\mathrm{K}$ rate in the genotype Bulldog but increased its concentration in Mesa-Sirsa (Table 9). The $1 / 4$ rate of nanoparticle $\mathrm{K}_{2} \mathrm{SO}_{4}$ recorded the lowest values of Cupper under salt stress in both genotypes. Manganese concentration in plant tissue increased with the application of $\mathrm{K}$ nanoparticle treatments compared to 
Table 8. Mean squares for chemical composition of micro-elements in plant tissue of two alfalfa genotypes evaluated under two salt levels ( 0 and $6 \mathrm{dS} \cdot \mathrm{m}^{-1}$ Electrical Conductivity) and three treatments of potassium nanoparticle rates $(1 / 10,1 / 8$, and $1 / 4)$ of the full $\mathrm{K}$ rate in Hoagland solution.

\begin{tabular}{|c|c|c|c|c|c|c|c|c|c|c|c|}
\hline $\begin{array}{l}\text { Source of } \\
\text { variation }\end{array}$ & DF & $\mathrm{Al}$ & B & $\mathrm{Cd}$ & $\mathrm{Cr}$ & $\mathrm{Cu}$ & $\mathrm{Fe}$ & $\mathrm{Mn}$ & $\mathrm{Zn}$ & $\mathrm{Ni}$ & $\mathrm{Pb}$ \\
\hline Genotypes & 1 & 2.81 & 121.17 & 40.66 & 0.21 & 5.31 & 70.86 & 592.59 & 3.05 & 0.0003 & $0.45^{*}$ \\
\hline Salt conc. & 1 & 0.00 & $753.7^{\star \star}$ & $908.3^{* *}$ & 0.65 & 0.40 & 355.34 & 13.87 & 11.02 & 0.00 & 0.24 \\
\hline Nano- $\mathrm{K}_{2} \mathrm{SO}_{4}$ rates & 3 & 12.6 & 432.79 & 131.48 & 5.46 & $0.57^{\star *}$ & 120.21 & $415.27^{\star}$ & $28.83^{*}$ & 0.0004 & 0.009 \\
\hline $\begin{array}{l}\text { Genotypes } \times \text { salt } \\
\text { concentration }\end{array}$ & 1 & 0.00 & 105.02 & 71.05 & 0.05 & 0.003 & 42.19 & 29.14 & 4.94 & 0.000 & 0.24 \\
\hline $\begin{array}{c}\text { Genotypes } \times \text { Na- } \\
\text { no- } \mathrm{K}_{2} \mathrm{SO}_{4} \text { rates }\end{array}$ & 3 & 2.84 & 237.28 & 41.48 & 2.97 & $5.76^{\star}$ & 259.94 & $583.48^{\star *}$ & 7.32 & 0.0004 & 0.009 \\
\hline Error & 20 & 6.57 & 95.03 & 66.77 & 1.37 & 1.34 & 101.52 & 65.33 & 7.56 & 0.0003 & 0.07 \\
\hline LSD & & 1.95 & 2.09 & 6.22 & 0.89 & 0.88 & 7.67 & 6.16 & 2.09 & 0.014 & 0.20 \\
\hline
\end{tabular}

DF: Degree of freedom, LSD: Least Significant Difference at $\alpha=0.05 .{ }^{\star}$ Significant at $P<0.05{ }^{*}$ Significant at $P<0.01$.

Table 9. Average mineral composition of micro-elements $\left(\mathrm{mg} \mathrm{kg}^{-1}\right)$ in plant tissue of two alfalfa genotypes evaluated under two salt levels ( 0 and $6 \mathrm{dS} \cdot \mathrm{m}^{-1}$ Electrical Conductivity) and three treatments of potassium nanoparticle rates $(1 / 10,1 / 8$, and $1 / 4)$ of the full $\mathrm{K}$ rate in Hoagland solution.

\begin{tabular}{|c|c|c|c|c|c|c|c|c|c|c|c|c|}
\hline \multirow{2}{*}{ Genotypes } & \multirow{2}{*}{ Salt level } & \multirow{2}{*}{ Treatments } & $\mathrm{Al}$ & B & $\mathrm{Cd}$ & $\mathrm{Cr}$ & $\mathrm{Cu}$ & $\mathrm{Fe}$ & $\mathrm{Mn}$ & $\mathrm{Zn}$ & $\mathrm{Ni}$ & $\mathrm{Pb}$ \\
\hline & & & \multicolumn{10}{|c|}{$\mathrm{mg} \mathrm{kg}^{-1}$} \\
\hline \multirow{5}{*}{ Bulldog } & $0 \mathrm{dS} \cdot \mathrm{m}^{-1}$ & $\begin{array}{l}\text { Control } \\
\text { (no salts) }\end{array}$ & $9.9 \pm 0.0$ & $71.9 \pm 12.6$ & $11.0 \pm 4.9$ & $1.5 \pm 0.4$ & $5.4 \pm 0.8$ & $72.4 \pm 14.1$ & $49.7 \pm 3.8$ & $21.2 \pm 1.2$ & $0.9 \pm 0.0$ & $2.6 \pm 0.8$ \\
\hline & & $\begin{array}{c}\text { Control } \\
\text { (with salts) }\end{array}$ & $9.9 \pm 0.0$ & $50.2 \pm 2.3$ & $23.5 \pm 2.5$ & $0.9 \pm 0.0$ & $5.7 \pm 0.4$ & $57.7 \pm 3.2$ & $44.4 \pm 7.1$ & $25.0 \pm 0.9$ & $0.9 \pm 0.0$ & $2.0 \pm 0.3$ \\
\hline & $6 \mathrm{dS} \cdot \mathrm{m}^{-1}$ & $1: 10$ & $9.9 \pm 0.0$ & $51.6 \pm 9.7$ & $20.8 \pm 5.1$ & $1.3 \pm 0.8$ & $5.1 \pm 0.6$ & $51.7 \pm 5.2$ & $38.0 \pm 6.3$ & $23.0 \pm 0.9$ & $0.9 \pm 0.0$ & $2.0 \pm 0.2$ \\
\hline & & $1: 8$ & $9.9 \pm 0.0$ & $67.9 \pm 5.0$ & $21.6 \pm 7.5$ & $1.7 \pm 0.7$ & $5.0 \pm 0.8$ & $45.5 \pm 8.8$ & $57.0 \pm 3.6$ & $21.2 \pm 3.0$ & $0.9 \pm 0.0$ & $2.0 \pm 0.2$ \\
\hline & & $1: 4$ & $11.4 \pm 2.7$ & $72.8 \pm 9.9$ & $17.9 \pm 6.9$ & $4.1 \pm 2.5$ & $4.5 \pm 0.2$ & $50.2 \pm 7.4$ & $49.9 \pm 12.1$ & $19.9 \pm 3.5$ & $0.9 \pm 0.0$ & $1.9 \pm 0.0$ \\
\hline \multirow{5}{*}{ Mesa-sirsa } & $0 \mathrm{dS} \cdot \mathrm{m}^{-1}$ & $\begin{array}{l}\text { Control } \\
\text { (no salts) }\end{array}$ & $9.9 \pm 0.0$ & $66.2 \pm 6.8$ & $10.5 \pm 3.2$ & $1.4 \pm 0.4$ & $5.0 \pm 0.2$ & $56.3 \pm 11.3$ & $39.7 \pm 6.0$ & $21.2 \pm 0.5$ & $0.9 \pm 0.0$ & $1.9 \pm 0.0$ \\
\hline & & $\begin{array}{c}\text { Control } \\
\text { (with salts) }\end{array}$ & $9.9 \pm 0.0$ & $56.3 \pm 21.4$ & $32.7 \pm 20.1$ & $1.1 \pm 0.3$ & $5.4 \pm 0.5$ & $49.2 \pm 2.9$ & $40.7 \pm 8.8$ & $21.8 \pm 1.9$ & $0.9 \pm 0.0$ & $1.9 \pm 0.0$ \\
\hline & $6 \mathrm{dS} \cdot \mathrm{m}^{-1}$ & $1: 10$ & $10.3 \pm 0.8$ & $79.1 \pm 5.6$ & $30.4 \pm 7.3$ & $3.1 \pm 1.9$ & $9.1 \pm 3.1$ & $61.2 \pm 3.8$ & $79.9 \pm 13.4$ & $24.3 \pm 4.4$ & $0.9 \pm 0.1$ & $1.9 \pm 0.0$ \\
\hline & & $1: 8$ & $9.9 \pm 0.0$ & $70.7 \pm 5.3$ & $25.3 \pm 5.8$ & $2.5 \pm 1.3$ & $5.9 \pm 0.9$ & $57.6 \pm 9.3$ & $62.8 \pm 9.0$ & $18.1 \pm 2.6$ & $0.9 \pm 0.0$ & $1.9 \pm 0.0$ \\
\hline & & $1: 4$ & $14.3 \pm 7.6$ & $72.6 \pm 2.5$ & $16.4 \pm 2.8$ & $2.5 \pm 1.0$ & $4.7 \pm 0.4$ & $73.4 \pm 20.3$ & $67.4 \pm 4.3$ & $19.7 \pm 4.7$ & $0.9 \pm 0.0$ & $1.9 \pm 0.0$ \\
\hline
\end{tabular}

the conventional full $\mathrm{K}$ rate under salt stress in both genotypes (Table 9). The $1 / 8$ rate of $\mathrm{K}$ nanoparticles recorded the highest tissue concentration of $\mathrm{Mn}$ in the genotype Bulldog (57 ppm) while the 1/10 rate recorded the highest accumulation in the genotype Mesa-Sirsa (79 ppm).

\subsection{Physiological Effect}

3.4.1. Electrolyte Leakage (EL)

Salt concentrations had a significant effect $(p<0.01)$ on electrolyte leakage in both genotypes (Table 10). The increase in salt concentration to $6 \mathrm{dS} \cdot \mathrm{m}^{-1}$ in- 
creased EL by an average of $6 \%$ in the salt sensitive genotype Bulldog and $3 \%$ in the salt tolerant genotype compared to the no-salt control (Table 11). The application of $\mathrm{K}$ nanoparticles had a significant effect $(p<0.01)$ on electrolyte leakage (Table 10). There was no interaction between genotypes and salt concentrations on EL but there was an interaction between genotypes and $\mathrm{K}$ nanoparticle rates $(p<0.01)$. In the salt sensitive genotype Bulldog, the $1 / 4 \mathrm{~K}$ nanoparticle rate resulted in lowest EL (68\%), while in the salt tolerant genotype Mesa-Sirsa, the 1/8 rate resulted in the lowest value of El (67.5\%) (Table 11).

\subsubsection{Proline}

There was a significant difference $(p<0.01)$ between the genotypes in proline concentration in plant tissue (Table 10). There was an interaction $(p<0.01)$ between genotypes and salt concentrations. Proline content in the salt tolerant genotype Mesa-Sirsa increased in the control with full $\mathrm{K}$ rate under salt stress compared to the no-salt control $\left(1.18 \mathrm{vs} 0.92 \mu \mathrm{mol} \cdot \mathrm{g}^{-1}\right)$. In the salt sensitive genotype Bulldog, there was no change in proline content in the control under salt compared to the no-salt control $\left(0.60 \mathrm{vs} 0.66 \mu \mathrm{mol} \cdot \mathrm{g}^{-1}\right)$. The application of nanoparticle $\mathrm{K}_{2} \mathrm{SO}_{4}$ had a significant effect $(p<0.05)$ on proline content in plant tissue of both genotypes. Adding $\mathrm{K}$ nanoparticles to the susceptible genotype resulted in an increase in proline content by $33 \%, 133 \%$, and $116 \%$ for the $\mathrm{K}$ rates $1 / 10,1 / 8$, and $1 / 4$, compared to the control under salt stress (Table 11). In the salt sensitive genotype Mesa-Sirsa, adding $\mathrm{K}$ nanoparticles resulted in dramatic decreases in proline content $(44 \%, 139 \%$, and $360 \%$ for the $1 / 10,1 / 8$, and $1 / 4 \mathrm{~K}$ rates) compared to the control with conventional $\mathrm{K}$ under salt stress (Table 11).

Table 10. Mean squares for electrolyte leakage, proline, and relative water content (RWC) in two alfalfa genotypes evaluated under two salt levels ( 0 and $6 \mathrm{dS} \cdot \mathrm{m}^{-1}$ Electrical Conductivity) and three treatments of potassium nanoparticle rates $(1 / 10,1 / 8$, and $1 / 4$ of the full $\mathrm{K}$ rate in Hoagland solution).

\begin{tabular}{ccccc}
\hline Source of variation & DF & Electrolyte leakage (\%) & Proline (\%) & RWC (\%) \\
\hline Genotypes & 1 & 0.09 & $1.75^{* *}$ & 3.46 \\
Salt conc. & 1 & $214.41^{* *}$ & 0.06 & 14.69 \\
Cuts & 1 & $201.70^{* *}$ & $6.11^{* *}$ & $1653.11^{* *}$ \\
Genotypes $\times$ salt conc & 1 & 4.12 & $0.15^{* *}$ & 16.60 \\
Nano- $\mathrm{K}_{2} \mathrm{SO}_{4}$ rates & 3 & $166.96^{* *}$ & $0.06^{*}$ & $787.34^{* *}$ \\
Genotypes $\times$ Nano- $\mathrm{K}_{2} \mathrm{SO}_{4}$ rates & 3 & $91.11^{* *}$ & $2.02^{* *}$ & $116.64^{*}$ \\
Genotypes $\times$ Nano- $\mathrm{K}_{2} \mathrm{SO}_{4}$ rates & 1 & $80.12^{* *}$ & $1.71^{* *}$ & 104.24 \\
$\times$ Cuts & 3 & 12.98 & $0.23^{* *}$ & $1084.61^{* *}$ \\
Nano- $\mathrm{K}_{2} \mathrm{SO}_{4}$ rates $\times \mathrm{Cuts}^{*}$ & 11.54 & 0.017 & 37.07 \\
Error & 20 & 1.773 & 0.0675 & 3.1773 \\
LSD & & & & \\
\hline
\end{tabular}

DF: Degree of freedom, LSD: Least Significant Difference at $\alpha=0.05 .{ }^{\star}$ Significant at $P<0.05{ }^{*}$ Significant at $P<0.01$. 
Table 11. Electrolyte leakage, proline and Relative water content (RWC) in plant tissue of two alfalfa genotypes evaluated under two salt levels ( 0 and $6 \mathrm{dS} \cdot \mathrm{m}^{-1}$ Electrical Conductivity) and three treatments of potassium nanoparticle rates $(1 / 10,1 / 8$, and $1 / 4)$ of the full $\mathrm{K}$ rate in Hoagland solution.

\begin{tabular}{|c|c|c|c|c|c|}
\hline Genotype & Salt level & Treatments & $\begin{array}{c}\text { Electrolyte leakage } \\
(\%)\end{array}$ & Proline (\%) & RWC (\%) \\
\hline \multirow{5}{*}{ Bulldog } & \multirow[t]{2}{*}{$0 \mathrm{dS} \cdot \mathrm{m}^{-1}$} & Control (no salts) & $70.30 \pm 4.16$ & $0.66 \pm 0.20$ & $95.41 \pm 20.72$ \\
\hline & & Control(with salts) & $75.45 \pm 2.04$ & $0.60 \pm 0.25$ & $62.64 \pm 16.43$ \\
\hline & \multirow{3}{*}{$6 \mathrm{dS} \cdot \mathrm{m}^{-1}$} & 1: 10 & $74.78 \pm 4.27$ & $0.80 \pm 0.23$ & $38.24 \pm 7.05$ \\
\hline & & $1: 8$ & $75.74 \pm 5.35$ & $1.40 \pm 0.92$ & $55.08 \pm 12.06$ \\
\hline & & $1: 4$ & $68.72 \pm 2.24$ & $1.30 \pm 0.85$ & $44.74 \pm 8.30$ \\
\hline \multirow{5}{*}{ Mesa-Sirsa } & \multirow[t]{2}{*}{$0 \mathrm{dS} \cdot \mathrm{m}^{-1}$} & Control (no salts) & $71.69 \pm 5.36$ & $0.92 \pm 0.57$ & $58.45 \pm 24.38$ \\
\hline & & Control(with salts) & $78.50 \pm 1.63$ & $1.18 \pm 0.76$ & $58.35 \pm 17.77$ \\
\hline & \multirow{3}{*}{$6 \mathrm{dS} \cdot \mathrm{m}^{-1}$} & $1: 10$ & $78.39 \pm 5.59$ & $0.66 \pm 0.36$ & $47.07 \pm 5.14$ \\
\hline & & $1: 8$ & $67.55 \pm 6.73$ & $0.26 \pm 0.02$ & $50.61 \pm 3.41$ \\
\hline & & $1: 4$ & $70.07 \pm 6.43$ & $0.22 \pm 0.09$ & $45.29 \pm 10.75$ \\
\hline
\end{tabular}

\subsubsection{Relative Water Contents (RWC)}

Salt stress reduced the relative water content in both genotypes (Table 11). The magnitude of reduction in the susceptible genotype Bulldog was much higher than the tolerant genotype Mesa-Sirsa (32.95\% compared to $0.1 \%$ ). The application of K nanoparticles had a significant effect $(p<0.01)$ on RWC. There was also an interaction between genotypes and $\mathrm{K}$ nanoparticle rates $(p<0.05)$. Compared to the control under salt (full rate of conventional $\mathrm{K}$ ), adding $\mathrm{K}$ nanoparticles resulted in a reduction in relative water content (RWC) in both genotypes. The 1/8 rate of $\mathrm{K}_{2} \mathrm{SO}_{4}$ nanoparticles exhibited the lowest reduction in RWC in both genotypes with $55.08 \%$ in Bulldog and $50.61 \%$ in Mesa-Sirsa, respectively (Table 11).

\subsubsection{Antioxidant Enzymes}

Salt concentration had a significant effect $(p<0.01)$ on superoxide dismutase (SOD) and catalase (CAT) activity in the two alfalfa genotypes (Table 12). There was a significant interaction $(p<0.05)$ between genotypes and salt concentrations for the activity of both enzymes. Catalase activity increased by nearly four folds in the salt sensitive genotype Bulldog and more than 2 folds in the salt tolerant genotype Mesa-Sirsa under salt stress compared to the no-salt control (Figure 1). Superoxide dismutase activity increased by $17 \%$ in the Bulldog genotype and by $35 \%$ in Mesa-Sirsa compared to the no-salt control. Application of $\mathrm{K}$ nanoparticles had a significant effect $(p<0.01)$ on catalase and SOD activities (Table 12). There was a significant interaction $(p<0.01)$ between genotypes and $\mathrm{K}$ nanoparticle rates for both catalase activity and SOD. In the salt sensitive genotype Bulldog, $\mathrm{K}$ nanoparticle rates of $1 / 10$ and $1 / 4$ resulted in catalase activities similar to the no-salt control but lower than the control under salt stress. (Figure 1). In the salt tolerant genotype Mesa-Sirsa, the $1 / 10$ and $1 / 4 \mathrm{~K}$ nanopar- 
Table 12. Mean squares comparison of Superoxide dismutase $\left(\mathrm{U} \mathrm{g} \mathrm{g}^{-1} \mathrm{FW}\right)$ and catalase ( $\mu \mathrm{mol} \mathrm{H}_{2} \mathrm{O}_{2} \mathrm{~min}^{-1} \cdot \mathrm{g}^{-1} \mathrm{FW}$ ) activity in plant tissue of two alfalfa genotypes evaluated under two salt levels ( 0 and $6 \mathrm{dS} \cdot \mathrm{m}^{-1}$ Electrical Conductivity) and three treatments of potassium nanoparticle rates $(1 / 10,1 / 8$, and $1 / 4$ of the full $\mathrm{K}$ rate in Hoagland solution).

\begin{tabular}{cccc}
\hline Source of variation & DF & $\begin{array}{c}\mathrm{SOD} \\
\left(\mathrm{Unit} \mathrm{g}^{-1} \mathrm{FW}\right)\end{array}$ & $\begin{array}{c}\mathrm{CAT} \\
\left(\mu \mathrm{mol} \mathrm{H}_{2} \mathrm{O}_{2} \mathrm{~min}^{-1} \cdot \mathrm{g}^{-1} \mathrm{FW}\right)\end{array}$ \\
\hline Genotypes & 1 & 29.35 & 1073.22 \\
Salt concentration & 1 & $1568.87^{* *}$ & $3294.18^{* *}$ \\
Genotypes $\times$ salt concentration & 1 & $259.60^{*}$ & $9702.60^{* *}$ \\
Nano- $\mathrm{K}_{2} \mathrm{SO}_{4}$ rates & 3 & $578.40^{* *}$ & $3176.84^{* *}$ \\
Genotypes $\times$ Nano- $\mathrm{K}_{2} \mathrm{SO}_{4}$ rates & 3 & $610.15^{* *}$ & $16508.40^{* *}$ \\
Error & 20 & 33.16 & 330.08 \\
LSD & & 9.6 & 13.84 \\
\hline
\end{tabular}

DF: Degree of freedom, LSD: Least Significant Difference at $\alpha=0.05 .{ }^{*}$ Significant at $P<0.05{ }^{*}$ Significant at $P<0.01$.

Table 13. Correlation between plant height $(\mathrm{cm})$ shoot dry weight $(\mathrm{g})$, electrolyte leakage (\%), relative water content (RWC), relative Yield (\%), Proline $\left(\mu \mathrm{mol} \mathrm{g} \mathrm{g}^{-1} \mathrm{FW}\right)$, root dry weight (gm), catalase $\left(\mu \mathrm{mol} \mathrm{H}_{2} \mathrm{O}_{2} \min ^{-1} \mathrm{~g}^{-1} \mathrm{FW}\right.$ ), and sodium oxide dismutase (SOD, $\mathrm{U}$ $\left.\mathrm{g}^{-1} \mathrm{FW}\right)$ in two alfalfa genotypes evaluated under two salt levels $\left(0\right.$ and $6 \mathrm{dS} \cdot \mathrm{m}^{-1}$ Electrical Conductivity) and three treatments of potassium nanoparticle rates $(1 / 10,1 / 8$, and $1 / 4$ of the full $\mathrm{K}$ rate in Hoagland solution).

\begin{tabular}{|c|c|c|c|c|c|c|c|c|c|}
\hline & $\begin{array}{l}\text { Plant } \\
\text { height }\end{array}$ & $\begin{array}{c}\text { Shoot } \\
\text { dry } \\
\text { weight }\end{array}$ & $\begin{array}{l}\text { Electrolyte } \\
\text { leakage }\end{array}$ & RWC & $\begin{array}{c}\text { Relative } \\
\text { yield }\end{array}$ & Proline & $\begin{array}{c}\text { Root } \\
\text { dry } \\
\text { weight }\end{array}$ & Catalase & $\mathrm{SOD}^{*}$ \\
\hline Plant Height & 1.00 & 0.03 & 0.04 & $-0.36^{* *}$ & $0.30^{*}$ & 0.16 & $0.37^{\star}$ & 0.15 & -0.12 \\
\hline Shoot dry weight & - & 1.00 & -0.03 & 0.10 & $0.74^{* *}$ & 0.22 & $0.58^{\star *}$ & 0.26 & -0.01 \\
\hline $\begin{array}{c}\text { Electrolyte lea- } \\
\text { kage }\end{array}$ & - & - & 1.00 & -0.03 & 0.07 & 0.05 & 0.05 & 0.20 & 0.29 \\
\hline RWC & - & - & - & 1.00 & -0.06 & 0.02 & $0.76^{* *}$ & $0.48^{\star *}$ & -0.08 \\
\hline Relative yield & - & - & - & - & 1.00 & 0.23 & $0.46^{* *}$ & 0.26 & 0.00 \\
\hline Proline & - & - & - & - & - & 1.00 & 0.16 & -0.20 & $0.40^{*}$ \\
\hline Root dry weight & - & - & - & - & - & - & 1.00 & $0.53^{* *}$ & -0.27 \\
\hline Catalase & - & - & - & - & - & - & - & 1.00 & $0.41^{*}$ \\
\hline SOD & - & - & - & - & - & - & - & - & 1.00 \\
\hline
\end{tabular}

${ }^{\star}$ Significant at $P<0.05 .{ }^{*}$ Significant at $P<0.01$.

ticle levels resulted in CAT activity higher than the no-salt control but lower than the control under salt (conventional $\mathrm{K}$ ). The $1 / 8 \mathrm{~K}$ nanoparticle level resulted in the highest CAT activity in both alfalfa genotypes (Figure 1). The application of $\mathrm{K}$ nanoparticles to the salt sensitive genotype Bulldog did not result in big changes in SOD compared to the control under salt except for the $1 / 8$ level which resulted in increase in SOD activity by $18 \%$ (Figure 2 ). In the salt tolerant genotype Mesa-Sirsa, all $\mathrm{K}$ nanoparticle rates resulted in decreases in SOD activity compared the control under salt (Figure 2). 


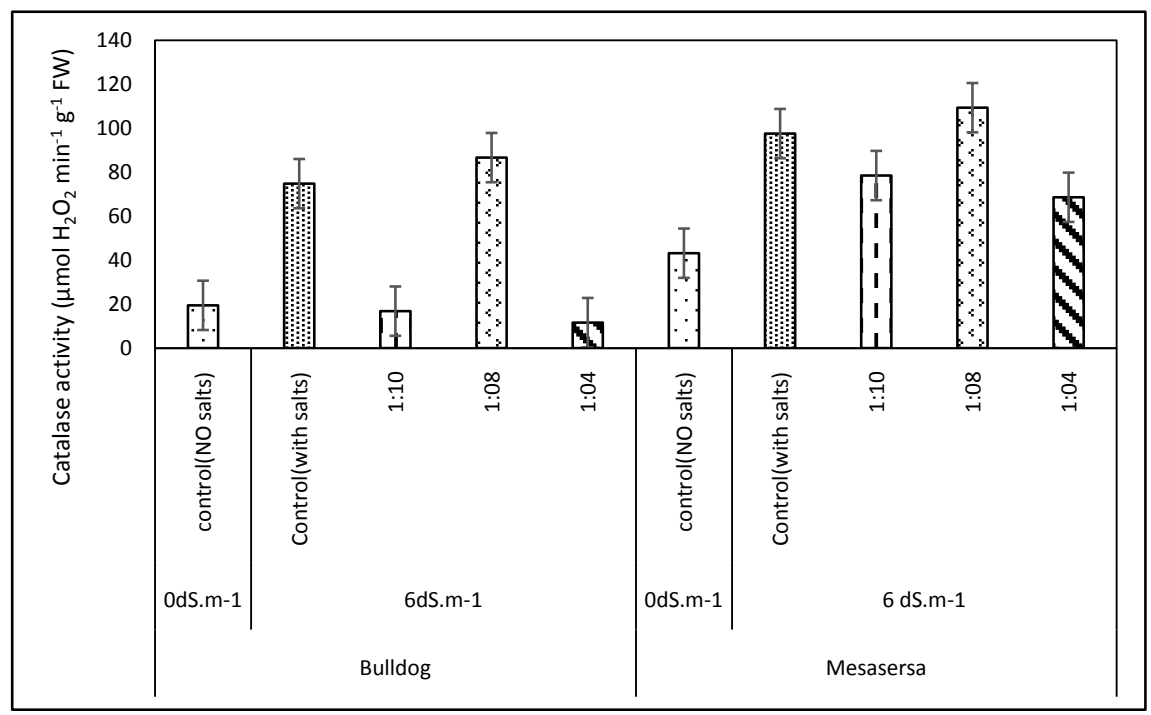

Figure 1. Catalase activity $\left(\mu \mathrm{mol} \mathrm{H}_{2} \mathrm{O}_{2} \mathrm{~min}^{-1} \cdot \mathrm{g}^{-1} \mathrm{FW}\right)$ in plant tissue of one salt sensitive (Bulldog) and one salt tolerant (Mesa-Sirsa) alfalfa genotypes evaluated under two salt levels ( 0 and $6 \mathrm{dS} \cdot \mathrm{m}^{-1}$ Electrical Conductivity) and three treatments of potassium nanoparticle rates $(1 / 10,1 / 8$, and $1 / 4$ of the full $\mathrm{K}$ rate in Hoagland solution).

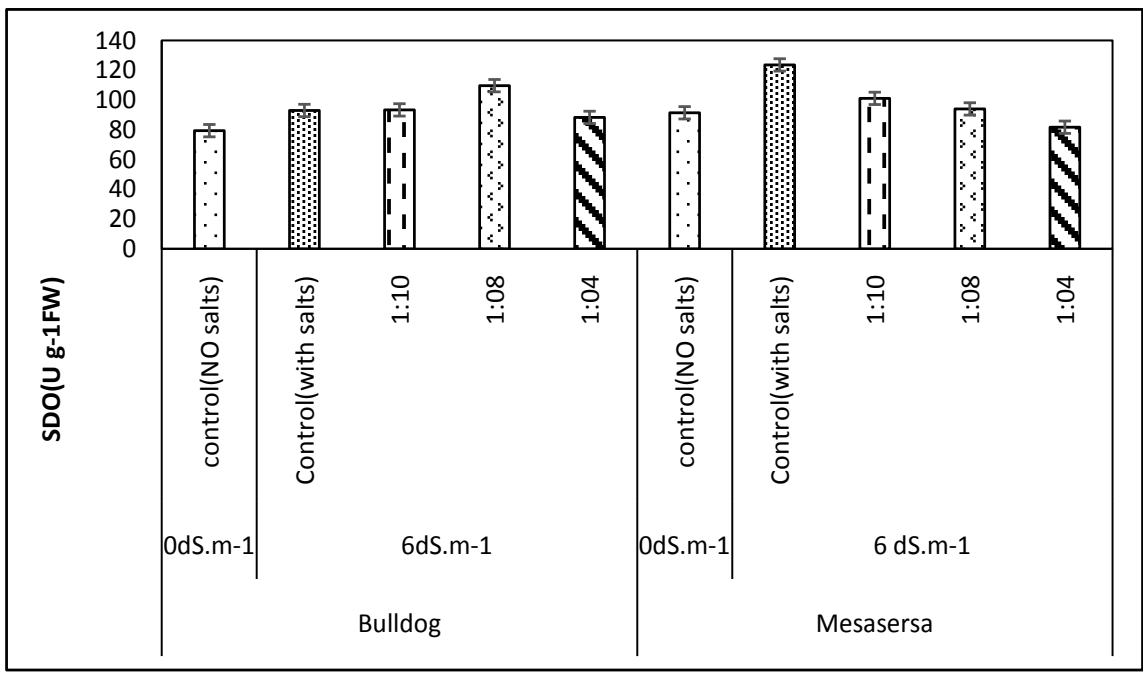

Figure 2. Superoxide dismutase activity $\left(\mathrm{U} \mathrm{g} \mathrm{g}^{-1} \mathrm{FW}\right)$ in plant tissue of one salt sensitive (Bulldog) and one salt tolerant (Mesa-Sirsa) alfalfa genotypes evaluated under two salt levels ( 0 and $6 \mathrm{dS} \cdot \mathrm{m}^{-1}$ Electrical Conductivity) and three treatments of potassium nanoparticle rates $(1 / 10,1 / 8$, and $1 / 4$ of the full $\mathrm{K}$ rate in Hoagland solution).

\subsection{Correlation between Physiological and Phenotypic Responses}

Across genotypes and treatments, there was a high positive correlation $(r=0.76, p$ $<0.01)$ between RWC and root dry weight but a low correlation $(r=0.10)$ between RWC and shoot dry weight (Table 13). This could be due to a decreased movement of water to above ground parts of the plant under salt stress (Krouma 2010), which translates into a decreased relative water content. RWC also showed significant positive correlation with CAT $(r=0.48, p<0.01)$. Electrolyte leakage showed a low positive correlation with CAT $(r=0.20, p<0.10)$ and $\operatorname{SOD}(r=$ 
$0.29, p<0.10)$. Proline concentration showed a significant positive correlation with SOD $(r=0.40, p<0.05)$ and low positive correlations with plant height and shoot dry weight ( $r=0.16$ and $r=0.22$ ) (Table 13). Catalase showed a significant positive correlation with SOD $(r=0.41, p<0.05)$, a significant positive correlation with root dry weight $(r=0.53, p<0.01)$, but a low positive correlation with shoot dry weight $(r=0.26, p<0.10)$.

\section{Discussion}

Nanotechnology applications in agriculture are still relatively underdeveloped even though they have potential in providing solutions to agricultural problems caused by conventional fertilizer management [28]. Salt stress constrains crop production by limiting water and essential nutrients uptake in addition to ions toxicity. Potassium $(\mathrm{K})$ is an essential nutrient that plays a major role in the biochemical and physiological processes underlying plant growth and metabolism. Potassium contribution to the survival of plants exposed to salt stress was documented [29]. The present study explores the effect of various levels of $\mathrm{K}$ nanoparticles on biomass production, mineral composition, and physiological response to salt stress of one salt-sensitive and one salt-tolerant alfalfa genotype. Increasing salt levels led to an increase in the cation exchange capacity of the soil. These changes increased the amount of exchangeable hydrogen $(\mathrm{H}+)$ in the soil leading to a decrease in soil $\mathrm{pH}$ especially under the $\mathrm{K}$ nanoparticle treatments.

The mean dry weights of plant shoots from the two cuts was reduced under salt stress compared to the no-salt control in both genotypes. Salinity limits leaf initiation and expansion thus reducing shoot growth and accelerating leaf abscission [30] [31] [32]. Salt stress also reduces growth rate by reducing cell elongation [33]. Application of $\mathrm{K}$ nanoparticles at the $1 / 8$ rate enhanced shoot dry weight to nearly the same levels as the no-salt control (2.66 g vs 2.97$)$ and higher than the control with full rate of conventional $\mathrm{K}$ under salt (2.66 g vs $2.44 \mathrm{~g}$ ) (Table 5). Under salt conditions, potassium plays an important role in the control of stomata opening and closing, tropisms, and photosynthesis [34]. Nanoparticles have the ability to enter plant cells and leaves, as well as transport chemicals into plant cells [35] [36]. It has also been reported that metals in nanoparticles can pass through the plants by adhering to root surfaces and entering the epidermis and cortex through the apoplast [37] [38] [39] [40]. Effectiveness of nanoparticles depends on several parameters including the chemical composition, size, surface reactivity, effective dose, and most importantly the plant species [41] [42].

The steep increase in $\mathrm{Na} / \mathrm{K}$ ratio under salt stress compared to the no-salt control is a clear indication that alfalfa plants of both genotypes absorbed more sodium than potassium. The higher ratios in the salt-tolerant genotype MesaSirsa is an indication that this genotype compartmentalize salt as a tolerance mechanism. Unlike $\mathrm{Na}, \mathrm{K}$ is an essential nutrient that is metabolized right away following absorption. The concentration of $\mathrm{K}$ in the cytoplasm has consistently 
been found in the range between 100 and $200 \mathrm{mM}$ [9]. In plants, $\mathrm{Na}$ ions has the potential to replace $\mathrm{K}$ in some of its functions and it was reported that in some plants, supplementation of $\mathrm{Na}$ in reduced amounts can eliminate $\mathrm{K}$ deficiency symptoms under limited K supply [43]. Under salt stress, K uptake by plants can be affected by the excessive presence of $\mathrm{Na}$ in the nutrient solution, and because of similarity, $\mathrm{Na}$ competes with $\mathrm{K}$ in plant uptake. There is also an antagonistic relationship between $\mathrm{K}$ and $\mathrm{Ca}$ absorption [44] [45]. The application of $\mathrm{K}$ nanoparticles resulted in an increase in Ca concentration especially with $1 / 8$ level compared to the no-salt control and the control with conventional $\mathrm{K}$ under salt stress. Magnesium concentration decreased under salt stress, but was higher under the $\mathrm{K}$ nanoparticle treatments compared to the control with conventional $\mathrm{K}$ under salt stress. The decrease in $\mathrm{Mg}^{+2}$ concentration under salt could be a result of stress and membrane permeability, but the increase with $\mathrm{K}$ nanoparticles could be the result of synergistic interaction between the two nutrients [51]. The application of $\mathrm{K}$ nanoparticles also increased $\mathrm{P}$ concentration in plant tissue but did not affect nitrogen content.

The effect of $\mathrm{K}$ nanoparticles on micro-nutrients under salt stress appeared to be genotype specific as the magnitude of increases were much higher in the salt-tolerant genotype Mesa-Sirsa, especially for B and $\mathrm{Mn}$, that are important for cell wall formation and photosynthesis. The lowest rate (1/10) of K nanoparticles resulted in the highest increases of $\mathrm{B}, \mathrm{Cu}, \mathrm{Mn}$, and $\mathrm{Zn}$. Szewczuk et al. [52] showed that application of low levels of $\mathrm{K}$ to apple trees increased the concentrations of $\mathrm{Fe}, \mathrm{Mn}$, and $\mathrm{Zn}$ in soil and plant tissue.

Electrolyte leakage (EL) is one of several physiological and biochemical responses in plants exposed to abiotic stress [53] [54]. Electrolyte leakage through plasma membrane has been suggested as an important trait for identification of salt tolerant plants [55] [56]. Electrolyte leakage has been related to $\mathrm{K}$ efflux from plant cells, mediated by cation conductance of the plasma membrane [57]. In this study, EL increased significantly $(p<0.01)$ upon exposure to salt stress in both genotypes compared to the no-salt control. Adding $\mathrm{K}$ nanoparticles at the $1 / 4$ and 1/8 rates resulted in decreases in EL in both genotypes. Similar results were reported in wheat plants following the application of NPK nanocomposites [58]. Nanoparticles also mitigated plasma membrane increased permeability and cell mortality in wheat plants [39] and in watermelon after foliar uptake of nanocomposites [29].

Proline plays an important role in reducing salinity damage and accelerating the repair processes following stress. Proline accumulation is necessary under salt stress, but may not be enough to give complete tolerance to salinity [59]. The significance of proline accumulation in osmotic adjustment varies with plant species [60]. In this study, proline content increased upon exposure to salt stress in the salt tolerant genotype Mesa-Sirsa but not in the salt sensitive Bulldog. Suggesting that proline which acts as an osmo-protectant, is associated with the mechanism of salt tolerance in this genotype [61]. Adding $\mathrm{K}$ nanoparticles increased significantly proline content in the salt sensitive genotype under salt 
stress but not in the tolerant genotype, suggesting the ability of $\mathrm{K}_{2} \mathrm{SO}_{4}$ nanoparticles to improve tolerance of plants to abiotic stress [62] [63].

Relative water content (RWC) indicates the amount of water in plant tissue, and is an expression of the ability of a plant to maintain water under stress conditions [64]. Relative water content decreased significantly in the salt sensitive genotype Bulldog upon exposure to salt stress but remained the same as the nosalt control in the salt tolerant genotype Mesa-Sirsa (Table 11). Adding K nanoparticles under salt stress resulted in further decreases of RWC in both alfalfa genotypes, even though with lesser magnitude at the $1 / 8$ rate. This $\mathrm{K}$ nanoparticle treatement resulted in the highest proline content and the lowest EL in both genotypes (Table 11), suggesting that this combination had maintained adequate cell turgor under salt stress [65].

Salt stress in plants is aggravated by the generation of reactive oxygen species (ROS) such as superoxide $\left(\mathrm{O}^{-2}\right)$, hydrogen peroxide $\left(\mathrm{H}_{2} \mathrm{O}_{2}\right)$ and hydroxyl radicals $(\mathrm{OH})$ (Smirnoff 1995). To prevent oxidative damages, plants mobilize antioxidant enzymes such as superoxide dismutase (SOD) and catalase (CAT) to scavenge ROS [66]. Exposure of the two alfalfa genotypes to salt stress resulted in significant increases in the activities of CAT and SOD in both genotypes with higher activities in the salt tolerant genotype (Figure 1 and Figure 2), suggesting a more effective defense mechanism against salt-induced $\mathrm{O}^{-2}$ generation in this genotype, as SOD catalyzes the conversion of the superoxide anion to $\mathrm{H}_{2} \mathrm{O}_{2}$ [67]. The increase in SOD was positively correlated with CAT and proline content which translated in an increase in RWC and root dry weights (Table 13). Increases in SOD activity were also observed in alfalfa cultivars exposed to salt stress [68] [67]. Higher constitutive and induced levels of SOD were observed in alfalfa cultivars tolerant to salt stress [69]. Similarly, higher activities of SOD and CAT were reported in wild, salt-tolerant tomato species than in the cultivated salt sensitive ones [70] [71]. Application of $\mathrm{K}$ nanoparticles especially the $1 / 8$ significantly enhanced the activity of both SOD and CAT enzymes in both genotypes, suggesting a possible positive interaction of these enzymes with the rise of cytosolic K [72].

\section{Conclusion}

The application of potassium sulfate nanoparticles on two alfalfa genotypes grown under two salt levels 0 and $6 \mathrm{dS} \cdot \mathrm{m}^{-1}$ enhanced plant growth, mineral concentration, and increased physiological response to salt stress. The rate of one-eighth $\mathrm{K}_{2} \mathrm{SO}_{4}$ nanoparticles exhibited the best effect on fresh and dry weights of shoots, relative yield, root length and root dry weight in both genotypes. Furthermore, the one-eighth nanoparticles rate was more effective in maintaining a lower $\mathrm{Na} / \mathrm{K}$ ratio and higher $\mathrm{Ca}, \mathrm{P}, \mathrm{Cu}, \mathrm{Mn}$, and $\mathrm{Zn}$ concentration in the plant tissue. The one-eighth $\mathrm{K}$ nanoparticle level also maintained lower electrolyte leakage and higher proline, relative water content, and higher superoxide dismutase and catalase activities. These results suggest that the application of $\mathrm{K}$ nanoparticles may have better efficiency than conventional $\mathrm{K}$ fertilizers 
in providing adequate plant nutrition and overcoming the negative effects of salt stress in alfalfa.

\section{References}

[1] Bertrand, A., Dhont, C., Bipfubusa, M., Chalifour, F.P., Drouin, P. and Beauchamp, C.J. (2015) Improving Salt Stress Responses of the Symbiosis in Alfalfa Using Salt-Tolerant Cultivar and Rhizobial Strain. Applied Soil Ecology, 87, 108-117.

[2] Manchanda, G. and Garg, N. (2008) Salinity and Its Effects on the Functional Biology of Legumes. Acta Physiologiae Plantarum, 30, 595-618.

https://doi.org/10.1007/s11738-008-0173-3

[3] Munns, R., James, A.J. and Lauchli, A. (2006) Approaches to Increasing the Salt Tolerance of Wheat and Other Cereals. Journal of Experimental Botany, 57, 10251043. https://doi.org/10.1093/jxb/erj100

[4] Ehsanpour, A.A. and Fatahian, N. (2003) Effects of Salt and Proline on Medicago sativa Callus. Plant Cell, Tissue and Organ Culture, 73, 53-56.

https://doi.org/10.1023/A:1022619523726

[5] Castroluna, A. (2009) Fisiología de la germinación y crecimiento de tres variedades de Medicago sativa bajo condiciones de estrés abiótico. Grade Thesis, National University of San Luís, San Luís, Argentina, 98.

[6] FAO (2002a) Crop Water Management Alfalfa. Land and Water Development Division, FAO, Rome. http://www.fao.Org/AG/aglW/cropwater/alfalfa.stm

[7] Rawlins, S.L. (1979) Irrigation to Minimize Salt Problems. Abstracts, 9th California Alfalfa Symposium Proceedings, Fresno, CA, 68-71.

[8] Emam, Y., Bijanzadeh, E., Naderi, R. and Edalat, M. (2009) Effect of Salt Stress on Vegetative Growth and Ion Accumulation of Two Alfalfa (L.) Cultivars. Desert, 14, 163-169.

[9] Shabala, S. and Pottosin, I.I. (2010) Potassium and Potassium-Permeable Channels in Plant Salt Tolerance. In: Demidchik, V. and Maathuis, F., Eds., Ion Channels and Plant Stress Responses, Springer, Berlin, Heidelberg, 87-110. https://doi.org/10.1007/978-3-642-10494-7_5

[10] Pettigrew, W.T. (2008) Potassium Influences on Yield and Quality Production for Maize, Wheat, Soybean and Cotton. Physiologia Plantarum, 133, 670-681. https://doi.org/10.1111/j.1399-3054.2008.01073.x

[11] Dong, H., Kong, X., Li, W., Tang, W. and Zhang, D. (2010) Effects of Plant Density and Nitrogen and Potassium Fertilization on Cotton Yield and Uptake of Major Nutrients in Two Fields with Varying Fertility. Field Crops Research, 119, 106-113.

[12] Botella, M.A., Martinez, V., Pardines, J. and Cerda, A. (1997) Salinity Induced Potassium Deficiency in Maize Plants. Journal of Plant Physiology, 150, 200-205.

[13] Coskun, D., Britto, D.T. and Kronzucker, H.J. (2010) Regulation and Mechanism of Potassium Release from Barley Roots: An in Planta ${ }^{42} \mathrm{~K}^{+}$Analysis. New Phytologist, 188, 1028-1038. https://doi.org/10.1111/j.1469-8137.2010.03436.x

[14] Mian, A., Oomen, R.J., Isayenkov, S., Sentenac, H., Maathuis, F.J. and Very, A.A. (2011) Over-Expression of an $\mathrm{Na}^{+}$- and $\mathrm{K}^{+}$-Permeable HKT Transporter in Barley Improves Salt Tolerance. The Plant Journal, 68, 468-479.

https://doi.org/10.1111/j.1365-313X.2011.04701.x

[15] Munns, R. and Tester, M. (2008) Mechanisms of Salinity Tolerance. Annual Review of Plant Biology, 59, 651-681.

https://doi.org/10.1146/annurev.arplant.59.032607.092911 
[16] Liu, R. and Lai, R. (2015) Potentials of Engineered Nanoparticles as Fertilizers for Increasing Agronomic Productions. Science of the Total Environment, 51, 131-139.

[17] Liu, R. and Lal, R. (2014) Synthetic Apatite Nanoparticles as a Phosphorus Fertilizer for Soybean (Glycine max). Scientific Reports, 4, Article No. 5686. https://doi.org/10.1038/srep05686

[18] Benzone, H.R.L., Rubenecia, M.R.U., Ultra, V.U. and Lee, S.C. (2015) Nanoparticles Fertilizer Affects the Growth, Development, and Chemical Properties of Rice. IJAAR, 7, 105-117.

[19] Liu, X., Zhang, D., Zhang, S., He, X., Wang, Y., Feng, Z., et al. (2005) Responses of Peanut to Nanoparticles Calcium Carbonate. Journal of Plant Nutrition and Fertilizer, 11, 385-389.

[20] Delfani, M., Firouzabadi, M.B., Farrokhi, N. and Makarian, H. (2014) Some Physiological Responses of Black-Eyed Pea to Iron and Magnesium Nanofertilizers. Communications in Soil Science and Plant Analysis, 45, 530-540. https://doi.org/10.1080/00103624.2013.863911

[21] Turner, N.C. (1981) Techniques and Experimental Approaches for the Measurement of Plant Water Status. Plant and Soil, 58, 339-366.

https://doi.org/10.1007/BF02180062

[22] Isla, R. and Aragüés, R. (2009) Response of Alfalfa (Medicago sativa L.) to Diurnal and Nocturnal Saline Sprinkler Irrigations. II: Shoot Ion Content and Yield Relationships. Irrigation Science, 27, 507-513.

https://doi.org/10.1007/s00271-009-0166-Z

[23] Bates, L., Waldren, R. and Teare, I. (1973) Rapid Determination of Free Proline for Water-Stress Studies. Plant and Soil, 39, 205-207. https://doi.org/10.1007/BF00018060

[24] Lutts, S., Kinet, J.M. and Bouharmont, J. (1996) NaCl-Induced Senescence in Leaves of Rice (Oryza sativa L.) Cultivars Differing in Salinity Resistance. Annals of Botany, 78, 389-398. https://doi.org/10.1006/anbo.1996.0134

[25] Bergmeyer, H.U. and Karlfried, G. (1970) Methoden der enzymatischen Analyse. Verlag Chemie Weinheim, 432.

[26] Beauchamp, C. and Fridovich I. (1971) Superoxide Dismutase: Improved Assays and an Assay Applicable to Acrylamide Gels. Analytical Biochemistry, 44, 276-287.

[27] Loneragan, J.F. and Snowball, K. (1968) Rate of Calcium Absorption by Plant Roots and Its Relation to Growth. Australian Journal of Agricultural Research, 20, 479490. https://doi.org/10.1071/AR9690479

[28] Mastronardi, E., Tsae, P., Zhang, X., Monreal, C.M., and DeRosa, M.C. (2015) Strategic Role of Nanotechnology in Fertilizers: Potential and Limitations. In: Rai, M., Ribeiro, C., Mattoso, L. and Duran, N., Eds., Nanotechnologies in Food and Agriculture, Springer, Berlin, 25, 67.

[29] Wang, W., Tarafdar, J.C. and Biswas, P. (2013) Nanoparticle Synthesis and Delivery by an Aerosol Route for Watermelon Plant Foliar Uptake. Journal of Nanoparticle Research, 15, 1417. https://doi.org/10.1007/s11051-013-1417-8

[30] Akram, M., Ashraf, M.Y., Ahmad, R., Rafiq, M., Ahmad, I. and Iqbal, J. (2010) Allometry and Yield Components of Maize (Zea mays L.) Hybrids to Various Potassium Levels under Saline Conditions. Archives of Biological Sciences, 62, 1053 1061. https://doi.org/10.2298/ABS1004053A

[31] Qu, C., Liu, C., Gong, X., Li, C., Hong, M., Wang, L. and Hong, F. (2012) Impairment of Maize Seedling Photosynthesis Caused by a Combination of Potassium Deficiency and Salt Stress. Environmental and Experimental Botany, 75, 134-141. 
[32] Kausar, A., and Gull, M. (2014) Effect of Potassium Sulphate on the Growth and Uptake of Nutrients in Wheat (Triticum aestivum L.) Under Salt Stressed Conditions. Journal of Agricultural Science, 6. https://doi.org/10.5539/jas.v6n8p101

[33] Szalai, G. and Janda, T. (2009) Effect of Salt Stress on the Salicylic Acid Synthesis in Young Maize (Zea mays L.) Plants. Journal of Agronomy and Crop Science, 195, 165-171. https://doi.org/10.1111/j.1439-037X.2008.00352.x

[34] Golldack, D.Q., Michalowski, F., Kamasani, U.R. and Bohnert, H.J. (2003) Salinity Stress Tolerant and Sensitive Rice Regulate AKT1-Type Potassium Channel Transcript Differently. Plant Molecular Biology, 51, 71-81. https://doi.org/10.1023/A:1020763218045

[35] Galbraith, D.W. (2007) Nanobiotechnology: Silica Breaks through in Plants. Nature Nanotechnology, 2, 272-273. https://doi.org/10.1038/nnano.2007.118

[36] Torney, F., Trewyn, B.G., Lin, V.S.Y. and Wang, K. (2007) Mesoporous Silica Nanoparticles Deliver DNA and Chemicals into Plants. Nature Nanotechnology, 2, 295-300. https://doi.org/10.1038/nnano.2007.108

[37] Zhu, H., Han., J., Xiao, J.Q. and Jin, Y. (2008) Uptake Translocation, and Accumulation of Manufactured Iron Oxide Nanoparticles by Pumpkin Plants. Journal of Environmental Monitoring, 10, 713-717. https://doi.org/10.1039/b805998e

[38] Du, W., Sun, Y., Ji, R., Zhu, J., Wu, J. and Guo, H. (2011) $\mathrm{TiO}_{2}$ and $\mathrm{ZnO}$ Nanoparticles Negatively Affect Wheat Growth and Soil Enzyme Activities in Agricultural Soil. Journal of Environmental Monitoring, 13, 822-828.

https://doi.org/10.1039/c0em00611d

[39] Zhao, L., Peng, B., Hernandez-Viezcas, J.A., Rico, C., Sun, Y., Peralta-Videa, J.R., et al. (2012) Stress Response and Tolerance of Zea mays to $\mathrm{CeO}_{2}$ Nanoparticles: Cross Talk among $\mathrm{H}_{2} \mathrm{O}_{2}$, Heat Shock Protein, and Lipid Peroxidation. ACS Nano, 6, 9615-9622. https://doi.org/10.1021/nn302975u

[40] Le, V.N., Rui, Y., Gui, X., Li, X., Liu, S. and Han, Y. (2014) Uptake, Transport, Distribution and Bio-Effects of $\mathrm{SiO}_{2}$ Nanoparticles in Bt-Transgenic Cotton. Journal of Nanobiotechnology, 12, 50.

[41] Ma, X., Geiser-Lee, J., Deng, Y. and Kolmakov, A. (2010) Interactions between Engineered Nanoparticles (ENPs) and Plants: Phytotoxicity, Uptake and Accumulation. Science of the Total Environment, 16, 3053-3061.

[42] Khodakovskaya, M.V., de Silva, K., Biris, A.S., Dervishi, E. and Villagarcia, H. (2012) Carbon Nanotubes Induce Growth Enhancement of Tobacco Cells. ACS Nano, 6, 2128-2135. https://doi.org/10.1021/nn204643g

[43] Wakeel, A., Farooq, M., Qadir, M. and Shubert, S. (2011) Potassium Substitution by Sodium in Plants. Critical Reviews in Plant Sciences, 30, 401-413. https://doi.org/10.1080/07352689.2011.587728

[44] Besson, K.C., Lyon, C.B. and Barrentine, M.W. (1944) Ionic Absorption by Tomato Plants as Correlated with Variations in the Composition of the Nutrient Medium. Plant Physiology, 19, 258-277. https://doi.org/10.1104/pp.19.2.258

[45] York, E.T., Bradfield, R. and Peech M. (1953) Calcium-Potassium Interactions in Soils and Plants. Reciprocal Relationship between Calcium and Potassium in Plants. Soil Science, 76, 481-492. https://doi.org/10.1097/00010694-195312000-00007

[46] Mcveoy, E.T. (1955) Interaction of Sodium and Potassium on Growth and miNeral Content of Fluccured Tobacco. Canadian Journal of Agricultural Science, 35, 294299.

[47] Osmond, C.B. (1966) Divalent Cation Absorption and Interaction in Triplex. Aus- 
tralian Journal of Biological Sciences, 19, 37-48.

[48] Lazaroff, N. and Pitman, M.G. (1966) Calcium and Magnesium Uptake by Barley Seedling. Australian Journal of Biological Sciences, 19, 991-1006. https://doi.org/10.1071/BI9660991

[49] Hylton, L.O., Ulrich, A. and Cornelius, D.R. (1967) Potassium and Sodium Interrelationships in Growth and Mineral Content of Italian Ryegrass. Agronomy Journal, 59, 311-314. https://doi.org/10.2134/agronj1967.00021962005900040007x

[50] Freeman, G.G. (1967) Studies on Potassium Nutrition of Plants. I. Effects of Potassium Concentration on Growth and Mineral Composition of Vegetable Seedlings in Sand Culture. Journal of the Science of Food and Agriculture, 18, 171-176. https://doi.org/10.1002/jsfa.2740180410

[51] Ding, Y., Luo, W. and Xu, G. (2006) Characterization of Magnesium Nutrition and Interaction of Magnesium and Potassium in Rice. Annals of Applied Biology, 149, 111-123. https://doi.org/10.1111/j.1744-7348.2006.00080.x

[52] Szewczuk, A., Komosa, A. and Gudarowska, E. (2009) Effect of Different Potassium Soil Levels and Forms of Potassium Fertilizers on Micro-Elemental Nutrition Status of Apple Trees in Early Fruition Period. Journal of Elementology, 14, 553-562.

[53] Garty, J., Weissman, L., Tamir, O., Beer, S., Cohen, Y., Karnieli, A., et al. (2000) Comparison of Five Physiological Parameters to Assess the Vitality of the Lichen Ramalina lacera Exposed to Air Pollution. Physiologia Plantarum, 109, 410-418. https://doi.org/10.1034/j.1399-3054.2000.100407.x

[54] Vainola, A. and Repo, T. (2000) Impedance Spectroscopy in Frost Hardiness Evaluation of Rhododendron Leaves. Annals of Botany, 86, 799-805. https://doi.org/10.1006/anbo.2000.1237

[55] Ashraf, M. and Ali, Q. (2008) Relative Membrane Permeability and Activities of Some Antioxidant Enzymes as the Key Determinants of Salt Tolerance in Canola (Brassica napus L.). Environmental and Experimental Botany, 63, 266-273.

[56] Tiwari, J.K., Munshi, A.D., Kumar, R., Pandey, R.N., Arora, A., Bhat, J.S. and Sureja, A.K. (2010) Effect of Salt Stress on Cucumber: $\mathrm{Na}^{+} / \mathrm{K}^{+}$Ratio, Osmolyte Concentration, Phenols and Chlorophyll Content. Acta Physiologiae Plantarum, 32, $103-$ 114.

[57] Demidchick, V., Straltsova, D., Medvedev, S.S., Pozhvanov, G.A., Sokolik, A. and Yurin, V. (2014) Stress-Induced Electrolyte Leakage: The Role of $\mathrm{K}^{+}$-Permeable Channels and Involvement in Programmed Cell Death and Metabolic Adjustment. Journal of Experimental Botany, 65, 1259-1270.

[58] Abdel-Aziz, H.M.M., Hassaneen, M.N.A. and Omer, A.M. (2016) Nano Chitosan-NPK Fertilizer Enhances the Growth and Productivity of Wheat Plants Grown in Sandy Soil. Spanish Journal of Agricultural Research, 1, 1-10.

[59] Petcue, E., Schitea, M. and Badea, D. (2007) The Behavior of Some Romanian Alfalfa Genotypes to Salt and Water Stress. Romanian Agricultural Research, No. 24, 51-54.

[60] El-Nakhlawy, F.S., Shaheen, M.A. and Al-Shareef, A.R. (2012) Response of Forage Yield, Protein and Proline Contents of Alfalfa Genotypes to Irrigation Water Salinity and Phosphorus Fertilizer. Journal of Food, Agriculture \& Environment, 10, 551-557.

[61] YuLei, M. and Shaozheng, L. (2000) Research on Salt Tolerance of Some Tree Species on Muddy Seashore of North China. International Seminar on "Prospects for Saline Agriculture, 10-12 April 2000, Islamabad (Pakistan).

[62] Kalteh, M., Alipour, Z.T., Ashraf, S., Aliabadi, M.M. and Nosratabadi, A.F. (2014) 
Effect of Silica Nanoparticles on Basil (Ocimum basilicum) under Salinity Stress. Journal of Chemical Health Risks, 4, 49-55.

[63] Siddiqui, M.H., Al-Whaibi, M.H., Faisal, M. and Al Sahli, A.A. (2014) Nano-Silicon Dioxide Mitigates the Adverse Effects of Salt Stress on Cucurbita pepo L. Environmental Toxicology and Chemistry, 33, 2429-2437. https://doi.org/10.1002/etc.2697

[64] Rad, J.S., Karimi, J., Mohsenzadeh, S., Rad, M.S. and Moradgohli, J. (2014) Evaluation $\mathrm{SiO}_{2}$ Nanoparticles Effects on Developmental Characteristic and Photosynthetic Pigment Contents of Zea mays L. Bulletin of Environment, Pharmacology and Life Sciences, 3, 194-201.

[65] Hayat, S., Hayat, Q., Alyemeni, M.N., Wani, A.S., Pichtel, J. and Ahmad, A. (2012) Role of Proline under Changing Environments. Plant Signaling \& Behavior, 7, 1456 1466. https://doi.org/10.4161/psb.21949

[66] Foyer, C.H. and Graham N. (2003) Redox Sensing and Signalling Associated with Reactive Oxygen in Chloroplasts, Peroxisomes and Mitochondria. Physiologia Plantarum, 119, 355-364. https://doi.org/10.1034/j.1399-3054.2003.00223.x

[67] Babakhani, B., Khavari-Nejad, R.A., Hassan-Sajedi, R., Fahimi, H. and Saadatmand, S. (2011) Biochemical Responses of Alfalfa (Medicago sativa L.) Cultivars Subjected to $\mathrm{NaCl}$ Salinity Stress. African Journal of Biotechnology, 55, 11433-11441.

[68] Wang, B., Kim, W.Y.H., Lee, H.S., Kim, K.Y., Deng, X.P. and Kwak, S.S. (2009) Analysis of Antioxidant Enzyme Activity during Germination of Alfalfa under Salt and Drought Stresses. Plant Physiology and Biochemistry, 47, 570-577.

[69] Wang, X.S. and Han, J.G. (2009) Changes of proline Content, Activity, and Active Isoforms of Antioxidative Enzymes in two Alfalfa Cultivars under Salt Stress. Agricultural Sciences in China, 4, 431-440.

[70] Shalata, A. and Tal, M. (1998) The Effect of Salt Stress on Lipid Peroxidation and Antioxidants in the Cultivated Tomato and Its Wild Salt Tolerant Relative Lycopersicon pennellii. Physiologia Plantarum, 104, 169-174. https://doi.org/10.1034/j.1399-3054.1998.1040204.x

[71] Koca, H., Ozdemir, F. and Turkan, I. (2010) Effect of Salt Stress on Chlorophyll Fluorescence, Lipid Peroxidation, Superoxide Dismutase and Peroxidase Activities of Cultivated Tomato (L. esculentum) and Its Wild Relative (L. pennellii). Environmental and Experimental Botany.

[72] Gholizadeh, S., Nemati, I. and Moradi, F. (2012) Effect of Supplemental Calcium and Potassium on Organic and Inorganic Solutes and Antioxidant Enzymes Activity in $\mathrm{NaCl}$ Stressed Alfalfa Seedlings. IJACS, 7, 377-385. 
Submit or recommend next manuscript to SCIRP and we will provide best service for you:

Accepting pre-submission inquiries through Email, Facebook, LinkedIn, Twitter, etc. A wide selection of journals (inclusive of 9 subjects, more than 200 journals)

Providing 24-hour high-quality service

User-friendly online submission system

Fair and swift peer-review system

Efficient typesetting and proofreading procedure

Display of the result of downloads and visits, as well as the number of cited articles Maximum dissemination of your research work

Submit your manuscript at: http://papersubmission.scirp.org/

Or contact ajps@scirp.org 